Title: Optimal design of cold-formed steel portal frames for stressedskin action using genetic algorithm

Authors: $\quad$ Duoc T. Phan ${ }^{\mathrm{a}}$, James B.P. Lim ${ }^{\mathrm{b} *}$, Tiku T. Tanyimboh ${ }^{\mathrm{c}}$, A.M. Wrzesien ${ }^{\mathrm{b}, \mathrm{c}}$, Wei Sha ${ }^{\text {b }}$, R.M. Lawson ${ }^{\mathrm{d}}$

${ }^{*}$ Corresponding Author: James B.P. Lim

${ }^{a}$ Department of Civil Engineering, Faculty of Engineering and Science, Universiti Tunku Abdul Rahman, Kuala Lumpur, 53300, Malaysia (formerly: School of Planning, Architecture and Civil Engineering, David Keir Building, Queen's University, Belfast, BT9 5AG, UK)

${ }^{b}$ School of Planning, Architecture and Civil Engineering, David Keir Building, Queen's University, Belfast, BT9 5AG, UK

${ }^{c}$ Department of Civil and Environmental Engineering, University of Strathclyde Glasgow, 107 Rottenrow, Glasgow, G4 ONG, UK

${ }^{d}$ Department of Civil Engineering, University of Surrey, Guildford, GU2 7XH, UK

Duoc T. Phan: Department of Civil Engineering, Faculty of Engineering and Science, Universiti Tunku Abdul Rahman, Kuala Lumpur, 53300, Malaysia (formerly: School of Planning, Architecture and Civil Engineering, David Keir Building, Queen's University, Belfast, BT9 5AG, UK)

Email: phantd@utar.edu.my

James B.P. Lim: SPACE, David Keir Building, Queen's University, Belfast, BT9 5AG, U.K.

Email: j.lim@qub.ac.uk

Tiku T. Tanyimboh: Department of Civil Engineering and Environmental Engineering, The University of Strathclyde Glasgow, 107 Rottenrow, Glasgow, G4 0NG, U.K. Email: tiku.tanyimboth@strath.ac.uk 
A.M. Wrzesien: Department of Civil Engineering and Environmental Engineering, The University of Strathclyde Glasgow, 107 Rottenrow, Glasgow, G4 0NG, U.K.

Email: a.wrzesien@strath.ac.uk

Wei Sha: SPACE, David Keir Building, Queen's University, Belfast, BT9 5AG, U.K.

Email: w.sha@qub.ac.uk

R. Mark Lawson: Department of Civil Engineering, University of Surrey, Guildford, GU2 7XH, U.K.

Email: m.lawson@surrey.ac.uk

Duoc T. Phan: $\quad$ PhD, Assistant Professor

James B.P. Lim: $\quad$ PhD, Lecturer

Tiku T. Tanyimboh: $\quad$ PhD, Senior Lecturer

Andrzej Wrzesien: PhD student

Wei Sha: $\quad$ PhD, Professor

R. Mark Lawson: $\quad \mathrm{PhD}$, Professor 


\section{Optimal design of cold-formed steel portal frames for stressed-skin action using genetic algorithm}

This paper describes a stressed-skin diaphragm approach to the optimal design of the internal frame of a cold-formed steel portal framing system, in conjunction with the effect of semi-rigid joints. Both ultimate and serviceability limit states are considered, using deflection limits as recommended by The Steel Construction Institute (SCI). Wind load combinations are included. The designs are optimized using a real-coded niching genetic algorithm, in which both discrete and continuous decision variables are processed. For a building with two internal frames, it is shown that the material cost of the internal frame can be reduced by as much as $53 \%$, compared with a design that ignores stressed-skin action.

Keywords: Cold-formed steel, portal frames, building topology, stressed-skin action, real-coded genetic algorithm, constrained evolutionary optimisation 


\section{Introduction}

In cold-formed steel portal frames, the eaves and apex joints can be formed through mechanical interlock of the steel sections (see Fig. 1(a)). As can be seen in Fig. 1(a), under an applied moment, matching swages in the brackets and channel-sections interlock to form a rigid joint. In laboratory tests described by Kirk [1], it was shown that smaller brackets were required than for the case of joints formed using plain channelsections (see Fig. 1(b) and (c)). In addition, only four bolts per connection were required as, owing to mechanical interlock, the primary purpose of the bolts is to prevent the brackets and channel-sections from separating.

Recently, Phan et al. [2] have described an ultimate limit state design optimization approach for such a rigid-jointed cold-formed steel portal framing system. In the frame analysis model, the joints were assumed to be rigid and capable of sustaining the full moment capacity of the channel-sections being connected. The objective function was the minimum material cost per square meter on plan (see Fig. 2) of the optimum cold-formed steel channel-sections used for the column and rafter members. Also, the design variables for building topology were the pitch of the frame and the frame spacing (see Fig. 2). As the joints were assumed rigid, the cost of the brackets was not included in the design optimization. In the optimum design of steel portal frames, many researches focused on designing portal frames using hot-rolled rather than cold-formed steel, in which genetic algorithm was successfully adopted as an optimizer [3-5], as well as other method, i.e. nonlinear programming, sequential algorithm [6-8].

However, in more general cold-formed steel portal framing systems, cold-formed steel channel-sections without swages are used for the column and rafter members (see Fig. 1(b-c)). As can be seen, the joints are formed through brackets bolted to the coldformed steel channel-sections being connected; typically nine bolts are used for each 
connection in practice.

As a result, two joint effects on the structural response should be taken into account. Firstly, owing to localised bolt-hole elongation, the joints are semi-rigid. To illustrate this, Fig. 3 shows a bolt-group rotating under moment. As the bolt-holes elongate, the bolt-group rotates around the centre of rotation. The effects of joint flexibility are increased frame deflections, and so serviceability deflections may be more important than for the case of a rigid-jointed frame. Table 1 shows serviceability deflection limits proposed by The Steel Construction Institute (SCI) [9] that will be used as the design criteria for the frame deflections; the frame parameters used for these limits are defined in Fig. 2.

Secondly, unlike rigid joints, moment is resisted by bolt forces developed in the web over the length of the bolt-group (see Fig. 4). As a result of these localized bolt forces, the moment capacity of the joints can be expected to be lower than that of the moment capacity of the channel sections; the strength of the joints can therefore be seen to be influenced by the size of the bolt-group [10-11]. In more general cold-formed steel portal framing systems, larger bolt-group sizes are required in order to increase both the rigidity and strength of the joints.

However, for steel clad portal frames, the inherent strength and stiffness of the metal cladding panels acts as a shear diaphragm (see Fig. 5), referred to as stressed-skin action [12-13]. Davies and Bryan [14] demonstrated that the effect of stressed-skin action reduces the sway and spread under applied loads when the gables are braced or sheeted. The shear stiffness of a completed sheeted panel takes into account factors such as the deformation of the sheeting due to distortion of the roof profile, slip in the sheet-purlin fasteners, seam fasteners between adjacent sheets, and distortion in purlin-rafter connections [15]. 
Research has demonstrated that a clad portal frame behaves differently from a bare frame due to the stiffening effect of the roof diaphragm [16]. With the introduction of higher grades of steel, portal frames have become lighter and hence more flexible. In such cases, depending on the ratio of the frame to cladding stiffness, the load is redistributed between adjacent frames and so in some design cases failure can occur in the cladding before first yield of a frame. Some of the authors who have contributed to this research are: Bates et al. [17], Bryan and Moshin [18], Strnad and Pirner [19], Davies et al. [20], and Heldt and Mahendran [21]. It should be noted that the research of these authors focuses on hot-rolled steel portal frames with eaves and apex joints that function as rigid.

However, high-strength, light-gauge, cold-formed steel portal frames with flexible joints are increasingly used for spans up to $20 \mathrm{~m}$. Full-scale tests on cold-formed steel portal frames with semi-rigid bolted moment connections and the inclusion of the stressed-skin effects have been described by Wrzesien et al. [22]. It was shown that coldformed steel portal frames with semi-rigid joints are sensitive to serviceability deflections, and hence the effects of stressed-skin action should not be ignored as they can lead to a significant reduction on deflections; uncalculated stressed-skin effects can potentially lead to tearing of the fixings [23].

In this paper, the design optimization of a cold-formed steel portal frame is described, in which stressed-skin action and the semi-rigidity of the joints are considered. A parametric study investigating the effect of stressed-skin action is conducted on different numbers of frames and cladding thicknesses. The design optimization uses a real-coded niching genetic algorithm (RC-NGA) to search for the optimum design.

For the optimum design accounting for stressed-skin action and partial strength of semi-rigid joints, such effects are determined based on the experimental researches [10- 
11, 22-24], which agree well with the British Standards BS5950 for cold-formed steel. Although BS 5950 is now superseded by the Eurocode 3, it should be noted that the design procedure described are not available in the Eurocodes; however, the research results are of value and independence of any design codes, especially for the study about cold-formed steel structures. Also, the data for characteristic value for cold-formed steel members obtained from industry is tested based on BS 5950. The loading and member checks are therefore performed based on the British Standards BS 5950. In this paper, the buildings are designed to both ultimate and serviceability limit states with all wind load combinations according to BS 6399 [25] considered.

No published research has considered all aspects of cold-formed steel frame and joint designs before. For this reason, this lengthy introduction is given to present the background to this work. Rigid joints in cold-formed steel are expensive to fabricate [1, 10], this paper will show that this is not necessary as a stressed skin design will result in the simpler joints. Applying genetic optimisation and stressed skin action to cold-formed steel portal frame structures is the uniqueness of this research. To limit the scope, consideration of the sizing, shape and lay out optimization, and possible conditions of hazard situation (elevated temperatures, fire), is not included.

\section{Structural analysis and design of the cold-formed steel portal}

\section{frame}

\subsection{Details of portal frame building}

A frame of span of $12 \mathrm{~m}$, height of eaves of $3 \mathrm{~m}$ and roof pitch of $10^{\circ}$ was adopted (see Fig. 6). Using this geometry of frame, six building cases were considered: Buildings A to F (see Fig. 7), in which the effect of two frame spacings of $4 \mathrm{~m}$ and $6 \mathrm{~m}$ were investigated. For each frame spacing, buildings having one, two and three internal frames 
were considered. The gable frames are assumed to be stiff both in- and out-of-plane.

The geometrical parameters of the frame shown in Fig. 2 are as follows: span of frame $L_{f}$, height to eaves $h_{f}$, pitch of frame $\theta_{f}$, and frame spacing (or bay spacing) $b_{f}$. It was assumed that the column bases are pinned. The frames were designed using coldformed steel profiles available from a UK cold-formed steel supplier (see Fig. 8). Table 2 shows a list of the available channel-sections [26]. It is worth noting that yield strength of cold-formed steel used for members is $390 \mathrm{~N} / \mathrm{mm}^{2}$ and elastic modulus is of 205 $\mathrm{kN} / \mathrm{mm}^{2}$. Strengths of column and rafter members, namely, moment capacity, axial capacity and shear capacity, are determined based on BS 5950 - Part 5 [27].

The positions of the purlins and side rails are also shown in Fig. 6. The purlins and side rails are assumed to be connected to the webs of the rafter and column members, respectively, thus providing both lateral and torsional restraint. A fixed spacing of $1.2 \mathrm{~m}$ and $1.0 \mathrm{~m}$ were applied for purlins and side rails, respectively, so that the effect of stressed-skin action can be compared directly between the different building cases, the channel-section C15018 was used for the purlin and side rails for all building cases.

Following consultation with industry, it was assumed that the combined material and fabrication cost of the brackets is $£ 2.0 / \mathrm{kg}$ [26], and that each bolt-group should comprises nine bolts.

\subsection{Details of the roof and wall sheeting}

Single skin $30 \mathrm{~mm}$ depth roof profile was used for both the roof and wall sheeting, with the yield strength of the sheeting of $390 \mathrm{~N} / \mathrm{mm}^{2}$ [28]. In this paper, two roof profiles with thicknesses of $0.5 \mathrm{~mm}$ and $0.7 \mathrm{~mm}$ were considered. Table 3 shows the parameters used in calculations of the diaphragm roof characteristic.

The roof diaphragm is divided into shear roof panels outlined by the eaves purlin, the ridge purlin and two adjacent rafters. Fig. 9 shows details of the fastener arrangement 
of the typical sheeting panel used in the UK that is fixed at every corrugation at both ends and at alternate corrugations at intermediate purlins. All shear panels are fixed along all four edges of the cladding profile.

For such arrangement of shear roof panel, the transverse shear flexibility, $c$, of the stressed-skin panel assembly is calculated as follows [29]:

$$
c=c_{1.1}+c_{1.2}+c_{2.1}+c_{2.2}+c_{2.3}+c_{3}
$$

where

$$
\begin{aligned}
& c_{1.1} \quad \text { is the profile distortion with fasteners at alternate trough of cladding } \\
& c_{1.2} \quad \text { is the shear strain of sheeting } \\
& c_{2.1} \quad \text { is the deformation of sheet to purlin fasteners } \\
& c_{2.2} \quad \text { is the deformation of seam fasteners } \\
& c_{2.3} \quad \text { is the fastener deformation of connections to rafters } \\
& c_{3} \quad \text { is the axial strain of purlins }
\end{aligned}
$$

In structural analysis, the transverse shear stiffness is the reciprocal of transverse shear flexibility. In this paper, the shear stiffness, $\mathrm{k}_{\mathrm{s}}$ (see Table 4), of the panel in the diagonal direction is calculated from the transverse shear flexibility as follows (Fig. 10):

$$
\mathrm{k}_{\mathrm{s}}=\frac{\mathrm{V}}{\Delta \cos ^{2} \theta}
$$

where

$\mathrm{V}=\Delta / c \quad$ is the shear capacity

$\Delta \quad$ is the displacement of other edge of the panel

It is worth noting that in some design cases, for the purlins fixed at spacing of around $1.2 \mathrm{~m}$, the use of $0.5 \mathrm{~mm}$ thick roofing profile fixed in alternate corrugations along its length is acceptable. Such a cladding panel is considered in this paper, as it 
would represent the lower bound of shear strength and stiffness of the roof diaphragm. In this paper, self-drilling and self-tapping screws of $5.5 \mathrm{~mm}$ diameter were used for both intermediate and edge purlins with spacings as summarised in Table 3. For the purlin to rafter connections, angle cleats and four M12 bolts were used (Fig. 9); in addition, 6.3 $\mathrm{mm}$ screws with washers were used for the seam connection and $5.5 \mathrm{~mm}$ screws with washers were used for the sheeting to rafter connections. Table 5 shows the mechanical properties of the screws. All the screws passing through the weather sheets use metal washers with EPDM rubber seal. The diameter of the washers was $16 \mathrm{~mm}$.

The design resistance of screws, $P_{d}$, fixed into thin sheeting is given by two formulae, according to BS 5950-5 Annex A:

$$
\begin{aligned}
P_{d} & =2.1 d t p_{y} \\
P_{d} & =3.2\left(t^{3} d\right)^{0.5} p_{y}
\end{aligned}
$$

where

$\mathrm{d} \quad$ is the screw diameter $(\mathrm{mm})$

$\mathrm{t} \quad$ is the thickness of the thinner steel (mm)

$p_{y} \quad$ is the design strength of the steel $\left(\mathrm{N} / \mathrm{mm}^{2}\right)$

These formulae include a partial factor of 1.25 . For $\mathrm{t}=1 \mathrm{~mm}, \mathrm{~d}=5.5 \mathrm{~mm}$ and $\mathrm{p}_{\mathrm{y}}$ $=390 \mathrm{~N} / \mathrm{mm}^{2}, \mathrm{P}_{\mathrm{d}}=4.5 \mathrm{kN}$ to Eq. (3) and $2.9 \mathrm{kN}$ to Eq. (4). It can be seen that Eq. (4) will generally control for the steel thicknesses used in sheeting.

However, shear resistances obtained from tests are significantly higher than design resistances, and are also influenced by the presence of a washer which helps to prevent rotation of the screw between thin sheets. The design values given in BS 5950-9 for the type of screws used in sheeting are higher than those obtained from Eqs. (3) and (4). 


\subsection{Frame loadings}

\subsubsection{Dead and live roof loads}

The loads applied to the frame were as follows.

Dead Load (DL): Cladding and service loads on the slope and self-weight of columns, rafters, purlins, and side rails of $0.15 \mathrm{kN} / \mathrm{m}^{2}$.

Live Load (LL): Snow load of $0.6 \mathrm{kN} / \mathrm{m}^{2}$

\subsubsection{Wind loads}

A dynamic wind pressure $\left(\mathrm{q}_{\mathrm{s}}\right)$ of $1.0 \mathrm{kN} / \mathrm{m}^{2}$ was adopted. Both transverse and longitudinal wind loads were considered. In accordance with BS 6399 [25], the design wind pressures (p) were calculated as follows.

$$
\mathrm{p}=\mathrm{q}_{\mathrm{s}}\left(\mathrm{C}_{\mathrm{pe}}-\mathrm{C}_{\mathrm{pi}}\right)
$$

where $C_{p e}$ is the external pressure coefficient and $C_{p i}$ is the internal pressure coefficient.

For buildings of normal permeability, without dominant openings, $\mathrm{C}_{\mathrm{pi}}$ has a minimum value of -0.3 for negative pressure, and a maximum value of +0.2 for positive pressure. Fig. 11 shows the six wind load cases considered (WLC1 to WLC6).

\subsubsection{Limit state design}

The frame was checked for the following four ultimate limit state load combinations (ULCs) [29].

$$
\begin{aligned}
& \mathrm{ULC} 1=1.4 \mathrm{DL}+1.6 \mathrm{LL} \\
& \mathrm{ULC} 2=1.2 \mathrm{DL}+1.2 \mathrm{LL}+1.2 \mathrm{WLC} \\
& \mathrm{ULC} 3=1.4 \mathrm{DL}+1.4 \mathrm{WLC} \\
& \mathrm{ULC} 4=1.0 \mathrm{DL}+1.4 \mathrm{WLC} \text { (for wind uplift) }
\end{aligned}
$$

where WLC denotes the wind load case 
The frame was also checked at the serviceability limit state for the following three serviceability load combinations (SLCs).

$$
\begin{aligned}
& \text { SLC1 }=1.0 \mathrm{LL} \\
& \text { SLC2 }=1.0 \mathrm{WLC}
\end{aligned}
$$

\subsection{Structural analysis and design}

Fig. 12 shows details of the beam idealization of a building having two internal frames. As can be seen, the gable-end frames are assumed to be fixed, which is justified as these frames are assumed to be fully clad and therefore stiff in-plane. For the out-ofplane direction, the frames can be constrained together at the position of the purlins and side rails (see Fig. 6). It should be noted that the effective length (buckling length in Eurocode 3) for member buckling check is determined from spacings of purlins and side rails. As shown in Section 2.1, owing to purlins and side rails connecting to columns and rafters through the web, the effective length for buckling check is constant for all loading cases, i.e. gravity loads or wind uplift load. The stressed-skin action is idealized using tension diagonal spring elements; the properties of the spring elements for the different building geometries are as shown in Table 4.

Fig. 13 shows details of the beam idealization of the internal frame. The semirigidity of the joints is idealised by a rotational spring at the centre of rotation of the boltgroup. The size of the bolt-groups (and brackets) is shown in Fig. 14. The rotational stiffness at the eaves of the bolt-group connecting the column and rafter to the eaves bracket are $\mathrm{k}_{\mathrm{ec}}$ and $\mathrm{k}_{\mathrm{er}}$, respectively. Similarly, the rotational stiffness at the apex of the bolt-group connecting the rafter to the apex bracket is $\mathrm{k}_{\mathrm{ar}}$. It is worth noting that the rotational stiffness of the bolt-group in semi-rigid joints $[10,11]$ is based on the bolt-hole elongation stiffness, $\mathrm{k}_{\mathrm{b}}$, as presented in Table 2. Also, the bolt-hole elongation stiffness depends on the thickness of the cold-formed steel plates, calculated based on equations 
proposed by Zandanfarrokh and Bryan [30]. The distance from the intersection of the members to the centre of rotation of each bolt-group is referred to the as the effective length of the bolt-group. For the eaves bracket, the effective length of the bolt-group connecting the column and rafter to the eaves bracket are $l_{\mathrm{ec}}^{\prime}$ and $l_{\mathrm{er}}^{\prime}$, respectively. Similarly, the effective length of the bolt-group connecting the rafter to the apex bracket is $l_{\mathrm{ar}}^{\prime}$. It is worth noting that the influence of imperfections and elongation of bolt holes has the effect on the rotational centre. However, owing to the deflection limits for stressed-skin design being small, the elongation of bolt holes is considered as not remarkable, and so the effect on rotational centre could be neglected.

In this paper, the first-order elastic analysis is adopted, which in-plane stability of frame is neglected, owing to the small displacement under the effect of stressed-skin action. However, if these results are required to include second-order effects, the amplified moment method could be adopted and applied to the loadings. The finite element program ANSYS was used for the purposes of the structural analysis. BEAM4 element was used for the columns and rafters; LINK10 was used to idealize the tension bracing that simulates the stressed- skin action. For the semi-rigidity of the joints, a rotational spring element of zero size connected with two coincident nodes at the joint positions (COMBIN40) was used [31]. It is assumed that the Bernoulli beam theory is applied for the member analysis which the effect of cross-section warping under shear stress action is neglected. It should be noted that albeit ANSYS element library provides the BEAM188 element that includes the warping magnitude, there is no option to input the section properties for the lip single-channel or back-to-back channel sections, in which the input for each dimension of cross-section is required.

Forty elements were used to model the column and rafter members, and five elements for eaves and apex brackets, in which such number of elements were found 
sufficient for the design process. For each load combination, bending moments, shear and axial forces for the frame are determined. The buildings were analysed under all of load combinations.

\subsection{Design constraints}

\subsubsection{Columns and rafters checks}

The columns and rafters were checked for axial force and bending moment, lateraltorsional buckling and combined shear and bending [27].

The combined tension and bending moment check for the rafters and columns is

$$
\frac{F_{t}}{P_{t}}+\frac{M_{x}}{M_{c x}} \leq 1
$$

where:

$\mathrm{F}_{\mathrm{t}} \quad$ is the applied tensile load at the critical section

$\mathrm{P}_{\mathrm{t}} \quad$ is the tensile capacity of a member, which is calculated from the effective net area $A_{e}$ of the section and steel yield strength $p_{y}$ of $390 \mathrm{~N} / \mathrm{mm}^{2}$

$\mathrm{M}_{\mathrm{x}} \quad$ is the applied bending moment at the critical section

$\mathrm{M}_{\mathrm{cx}}$ is the moment capacity in bending $\mathrm{M}_{\mathrm{c}}$ about the $\mathrm{x}$ axis (see Table 2).

The combined compression and bending moment were checked for local capacity at positions having greatest bending moment and axial compression, as well as for lateraltorsional buckling.

For the local capacity check

$$
\frac{F_{c}}{P_{c s}}+\frac{M_{x}}{M_{c x}} \leq 1
$$

where:

$\mathrm{F}_{\mathrm{c}} \quad$ is the applied compression load at the critical section 
$\mathrm{P}_{\mathrm{cs}} \quad$ is the short strut capacity subjected to compression, which is calculated from the effective net area $A_{e}$ of the section and steel yield strength $p_{y}$ of $390 \mathrm{~N} / \mathrm{mm}^{2}$

For the lateral-torsional buckling check

$$
\frac{F_{c}}{P_{c}}+\frac{M_{x}}{M_{b}} \leq 1
$$

where:

$\mathrm{P}_{\mathrm{c}} \quad$ is the axial buckling resistance in the absence of moment

$\mathrm{M}_{\mathrm{b}} \quad$ is the lateral resistance moment about the major axis

For members subjected to both shear and bending moment, the webs of members should be designed to satisfy the following relationship

$$
\left(\frac{F_{v}}{P_{v}}\right)^{2}+\left(\frac{M_{x}}{M_{c x}}\right)^{2} \leq 1
$$

where:

\footnotetext{
$F_{v}$ is the shear force associated with the bending moment $M_{x}$ at the same section

$\mathrm{P}_{\mathrm{v}} \quad$ is the shear capacity or shear buckling resistance
}

\subsubsection{Joint checks}

In this paper, the partial strength of the joints is taken into account through design checks [27, 32]:

$$
\begin{aligned}
& \frac{\mathrm{F}_{\mathrm{w}}}{\mathrm{P}_{\mathrm{w}}} \leq 1 \\
& 1.1 \frac{\mathrm{F}_{\mathrm{w}}}{\mathrm{P}_{\mathrm{w}}}+\frac{\mathrm{M}_{\mathrm{x}}}{\mathrm{M}_{\mathrm{cx}}} \leq 1.5
\end{aligned}
$$

where: 
$\mathrm{F}_{\mathrm{w}} \quad$ is the concentrated web load at the joint

$\mathrm{P}_{\mathrm{w}} \quad$ is the concentrated web load resistance

The crushing resistance $\left(\mathrm{P}_{\mathrm{w}}\right)$ of the web under concentrated load [27] is given by:

$$
\mathrm{P}_{\mathrm{w}}=\mathrm{t}^{2} \mathrm{C}_{7} \mathrm{p}_{\mathrm{y}}\left\{8.8+1.1(\mathrm{~N} / \mathrm{t})^{1 / 2}\right\}
$$

in which $\mathrm{C}_{7}=1.20$ if $\mathrm{D} / \mathrm{t}>150$ and $\mathrm{C}_{7}=1+(\mathrm{D} / \mathrm{t}) / 750$ if $\mathrm{D} / \mathrm{t} \leq 150$

where:

$\mathrm{t}$ is thickness of the web

$\mathrm{C}_{7} \quad$ is the experimental constant [27]

$\mathrm{p}_{\mathrm{y}} \quad$ is the design strength of steel

$\mathrm{N} \quad$ is the actual length of bearing (or connection length)

D is the overall web depth of the cross section

\section{c. Ultimate limit state check for stressed-skin panels}

In accordance with BS 5950 - Part 9 [13], the roof diaphragm transfers the horizontal load to stiff gables reducing the level of loading applied to the internal frames. This allows lightening of the internal frames. When the ultimate shear capacity of the roof diaphragm is reached the load is no longer redistributed and the internal frames are subjected to a larger load. The following check must therefore be satisfied if stressed-skin design is to be used safely

$$
\frac{V_{d, u}}{V_{d, \text { theory }}} \leq 1
$$

where:

$V_{d, u} \quad$ is the applied shear force at the ultimate limit state loading along the diaphragm expressed as a diagonal force, obtained from ANSYS model 
$V_{d, t h e o r y}$ is the design shear capacity of the diaphragm expressed as a diagonal force

It should be noted that the design shear capacity (shear strength), $V_{d, \text { theory }}$, of the shear roof panel is obtained based on the seam capacity and shear connector fastener capacity, as shown in Table 5 [29]. The diagonal force is also determined following the same procedure as shown for the diagonal shear stiffness.

\section{d. Serviceability checks}

Cold-formed steel portal frames have flexible members and joints, and so there is often a problem of tearing in the cladding fixings due to differential deflection between adjacent frames [22-24]. Deflection limits in Table 1 are used.

The serviceability of the cladding is checked at serviceability load (Eq. 13) to prevent tearing of cladding $[22,23]$ :

$$
\frac{V_{d, s}}{0.6 V_{d, \text { theory }}} \leq 1
$$

where:

$V_{d, s} \quad$ is the applied shear force along the diaphragm expressed as a diagonal force under serviceability load

\section{Design Optimization Model}

The objectives of the design optimization are to satisfy the design requirements and minimize the cost of the channel-sections and brackets for the internal frame per unit floor area (see Fig. 2). The material cost depends on the frame spacing, frame geometry, 
cross-section sizes of members, and sizes of eaves and apex bracket, and can be expressed as

$$
\mathrm{C}=\frac{1}{\mathrm{~L}_{\mathrm{f}} \mathrm{b}_{\mathrm{f}}}\left[\sum_{\mathrm{i}=1}^{\mathrm{m}} \mathrm{c}_{\mathrm{i}} \mathrm{l}_{\mathrm{i}}+\mathrm{w}_{\mathrm{br}} \mathrm{c}_{\mathrm{br}}\right]
$$

where:

$\mathrm{C} \quad$ is the cost of the building per square meter of floor area

$c_{i} \quad$ are the costs per unit length of cold-formed steel sections for frame members and secondary members

$l_{i} \quad$ are the lengths of cold-formed steel frame members

$\mathrm{m} \quad$ is the number of structural members in the portal frame

$c_{b r} \quad$ is the cost per unit weight of the brackets

$\mathrm{w}_{\mathrm{br}} \quad$ is the total weight of the brackets

The decision variables are of two types:

(i) The sizes of the columns and rafters are selected from a list of sections available in the UK (see Table 2)

(ii) The lengths of bolt-groups, namely, $\mathrm{a}_{\mathrm{ec}}, \mathrm{a}_{\mathrm{er}}$ and $\mathrm{a}_{\mathrm{ar}}$ (see Fig. 4) are continuous within the range $[200 \mathrm{~mm}, 2000 \mathrm{~mm}$ ]. It should be noted that the widths of the bolt-groups depend on the depth of the members.

The unit costs per meter length of the channel-sections are also shown in Table 2. As mentioned in Section 2.1, the combined material and fabrication costs for manufacturing the brackets are assumed to be $£ 2.0 / \mathrm{kg}$. The cost objective function is minimized subject to the design constraints in Eqs. (7)-(15).

The optimization model is solved with a genetic algorithm that employs constraint violation penalties. All essential design constraints should be satisfied and, consequently, the constraints are normalised to standardize the constraint violations. The normalized 
forms of the design constraints or unity-factors, given in Eqs. (7)-(15), are expressed as follows

$\mathrm{g}_{1}=\frac{\mathrm{F}_{\mathrm{t}}}{\mathrm{P}_{\mathrm{t}}}+\frac{\mathrm{M}_{\mathrm{x}}}{\mathrm{M}_{\mathrm{cx}}}-1 \leq 0$

$\mathrm{g}_{2}=\frac{\mathrm{F}_{\mathrm{c}}}{\mathrm{P}_{\mathrm{cs}}}+\frac{\mathrm{M}_{\mathrm{x}}}{\mathrm{M}_{\mathrm{cx}}}-1 \leq 0$

$\mathrm{g}_{3}=\frac{\mathrm{F}_{\mathrm{c}}}{\mathrm{P}_{\mathrm{c}}}+\frac{\mathrm{M}_{\mathrm{x}}}{\mathrm{M}_{\mathrm{b}}}-1 \leq 0$

$g_{4}=\left(\frac{F_{v}}{P_{v}}\right)^{2}+\left(\frac{M_{x}}{M_{c x}}\right)^{2}-1 \leq 0$

$\mathrm{g}_{5}=\frac{\mathrm{F}_{\mathrm{w}}}{\mathrm{P}_{\mathrm{w}}}-1 \leq 0$

$\mathrm{g}_{6}=\frac{1}{1.5}\left(1.1 \frac{\mathrm{F}_{\mathrm{w}}}{\mathrm{P}_{\mathrm{w}}}+\frac{\mathrm{M}_{\mathrm{x}}}{\mathrm{M}_{\mathrm{cx}}}\right)-1 \leq 0$

$g_{7}=\frac{V_{d, u}}{V_{d, \text { theory }}}-1 \leq 0$

$\mathrm{g}_{8}=\frac{\delta_{\mathrm{e}}}{\delta_{\mathrm{e}}^{\mathrm{u}}}-1 \leq 0$

$\mathrm{g}_{9}=\frac{\delta_{\mathrm{a}}}{\delta_{\mathrm{a}}^{\mathrm{u}}}-1 \leq 0$

$g_{10}=\frac{V_{d, s}}{0.6 V_{d, \text { theory }}}-1 \leq 0$

where

$\delta_{\mathrm{e}} \quad$ is the horizontal deflection at eaves under the action of serviceability load

$\delta_{\mathrm{a}} \quad$ is the vertical deflection at apex under the action of serviceability load $\delta_{a}^{u}$ and $\delta_{e}^{u} \quad$ are the maximum permissible vertical and horizontal deflections, respectively. 


\section{Computational Solution}

A real-coded genetic algorithm was coded to solve the optimization problem in Eqs. (16) and (13). A characteristic of real-coded GAs is that genetic operators are directly applied to the design variables without coding and decoding as with binary GAs. Solving optimization problems using real-coded GAs is therefore less cumbersome when compared to the binary-coded GAs. The algorithm used in this paper randomly generates a set of solutions known as initial population. From this population, the next generation of solutions is evolved by conducting three genetic operations: binary tournament selection, crossover, and mutation. The tournament selection process is conducted by picking two solutions at random from the current population. The solution with a better fitness value is selected for the next operation. The process of random selection ensures that the best solutions in the population will not dominate the mating pool, as in the proportional selection method. The diversity of the population is thus preserved to increase the exploration component of the algorithm. The best individuals in the population are retained and carried forward unchanged to the next generation. Two individuals are preserved for the next generation in the elitism procedure used here. The rest of the new population is created by the three genetic operators of selection, crossover and mutation applied to the entire current population including elite individuals.

Simulated binary crossover (SBX) [33] and polynomial mutation [34,35] were applied to create the new individuals for the next generation. The SBX operator picks at random two solutions in the current population, known as parents to create two offspring symmetrically to avoid a bias toward any particular parent solution in a single crossover operation. The polynomial mutation is also a stochastic procedure that creates a new solution in the vicinity of a parent solution. Niching may be applied to help maintain the 
diversity of the population throughout the evolutionary process to prevent premature convergence. Niching method aims to increase a competition between solutions in the same neighbourhood during selection for crossover. If the normalised Euclidean distance between two solutions is smaller than an empirical user-defined critical value known as niching radius, that is taken as 0.25 in this paper, these solutions then compete against each other for selection for subsequent crossover. Also, a mating restriction may be imposed to prevent individuals in different neighbourhoods or niches from mating with each other. While niching helps maintain diversity, the mating restriction helps intensify the search within individual niches. This affects multiple parallel searches and increases the probability of achieving a (near) global optimum solution [36]. A flow chart that shows the overall solution approach is shown in Ref. [5].

Penalty functions may be used to address constraints and thus define the relationship between the objective function and constraints. This effectively transforms a constrained problem to an unconstrained one [37] and defines the fitness function used to assess the quality of the solutions the genetic algorithm evolves. The fitness function adopted here has the form:

$$
F=C\left(1+\sum_{i=1}^{n} C V P_{i}\right)
$$

where:

$\mathrm{F} \quad$ is the fitness function

$C V P_{i}$ is the constraint violation penalty for the $i$ th constraint

$\mathrm{n} \quad$ is the number of design constraints

Penalty values were imposed in proportion to the severity of constraint violation. It was found that two levels of constraint violation as shown in Eq.19 provided satisfactory results. 


$$
C V P_{i}=\left\{\begin{array}{clc}
0 & \text { if } & g_{i} \leq 0 \\
g_{i} & \text { if } & 0<g_{i} \leq 0.1 \\
10 g_{i} & \text { if } & g_{i}>0.1
\end{array} \quad(\mathrm{i}=1, \ldots, \mathrm{n})\right.
$$

The proposed optimization procedure aims to minimize the value of the fitness function $F$ (Eq. 18). This is achieved by simultaneously minimizing the cost $\mathrm{C}$ and reducing the penalty $C V P_{i}$ to zero. Low-cost solutions that are feasible or marginally infeasible will yield smaller fitness values, and consequently are selected preferentially by the tournament selection operator. The optimization procedure is summarised in the flow chart in Ref. [5]. Eq. (19) has the advantage that near-feasible cost-effective solutions can survive while highly infeasible solutions are eliminated more quickly. In this way feasible solutions that are not cost-effective will tend to be dominated by marginally infeasible cost-effective solutions. This effectively increases the selection pressure.

\section{Results and Discussion}

To investigate the effects of stressed-skin action, the frames were first designed without stressed-skin action with the joints either rigid and full-strength or semi-rigid and partial strength. Rigid and full-strength joints were considered as designers in practice often make this assumption on the basis that the beneficial effects of stress-skin action are ignored. Only for the case of the semi-rigid and partial strength joints, were the frames designed with stressed-skin action.

The optimisation was carried out using a laptop computer $(2.0 \mathrm{GHz} \mathrm{CPU}, 2.0 \mathrm{~GB}$ RAM). The GA parameters used are as follows: population size $=80$; crossover probability $\mathrm{p}_{\mathrm{c}}=0.9$; mutation probability $\mathrm{p}_{\mathrm{m}}=0.1$; niching radius $=0.25$; termination criterion $=200$ generations (i.e. the maximum number of function evaluations allowed 
was 16000); distribution coefficient for mutation $=1.0$; distribution coefficient for crossover $=1.0$. The sensitivity analysis carried out showed that the algorithm achieves good results consistently with these parameter values. The optimization algorithm was executed 10 times for each of the cases described below. The initial populations were generated randomly. Satisfactory convergence was achieved as illustrated in Fig. 15. Fig. 15 shows that diversity within the population of solutions is maintained in all the generations in the optimization and helps provide assurance the convergence achieved is not spurious. Additional details and results including the optimized section sizes are available in Ref. [5].

\subsection{Frame spacing of $6 \mathrm{~m}$ : without stressed-skin action}

Table 6(a) summarises the optimal solution of the frame for both the rigid and semi-rigid joint assumptions. As can be seen the constraints reported have been separated into the gravity load design and the wind load design. For the case of the rigid joint assumption, the constraint of combined axial and bending moment governs the design, i.e., $\mathrm{g}_{2}=-0.16$, under ULC2 with WLC4. The slack (i.e. $\mathrm{g}_{2}<0$, the critical $\mathrm{g}$ value not quite near 0 ) shows that the solution has some redundancy to carry some additional load beyond the design specifications. On the other hand, for the case of the semi-rigid joint assumption, the constraint of the horizontal deflection at the eaves under SLC2 with WLC4 now governs, i.e. $\mathrm{g}_{8}=0$. It can be expected that the serviceability governs since the flexibility of the frame has increased.

It should be noted that both solutions have the same cost of the material of the column and rafter sections of $£ 6.60 / \mathrm{m}^{2}$. This can be attributed to the fact that the members are chosen from discrete section sizes. As previously noted, for the case of the rigid joint assumption, the design has some spare capacity to carry more load. 
Nevertheless, ignoring the semi-rigidity of the joints has in this case led to the same section sizes for the members. However, fabricating rigid joints is more complicated (Section 1). Still, the semi rigid joint yields a more costly solution effectively. However, allowing for stressed-skin action in fact reduces the overall cost as explained in the next section.

\subsection{Frame spacing of $6 \mathrm{~m}$ : with stressed-skin action}

Table 6(b) and (c) summarises the results of the optimization when stressed-skin action is included for cladding thicknesses of $0.5 \mathrm{~mm}$ and $0.7 \mathrm{~mm}$, respectively. It should be noted these results are for the semi-rigid joint assumption. Building lengths of 24,18 and $12 \mathrm{~m}$ were considered with, respectively, three, two and one internal frames. The main differences between these three design cases are the number of internal frames and the building length.

The significant result here is that stressed-skin action in fact reduces the cost of the frames and the total cost. For the cladding thickness of $0.5 \mathrm{~mm}$, as can be seen, the cost of material reduces as the number of internal frames decreases. However, the decrease in cost of material for the column and rafter sections between the building with three internal frames and the building with one internal frame is only $7 \%$. On the other hand, for the cladding thickness of $0.7 \mathrm{~mm}$, for the same comparison the decrease in cost of material is $31 \%$. This means that stressed-skin action is strengthened, and thus more effective in reducing the total cost of material, with thicker cladding, even just by $0.2 \mathrm{~mm}$ or $40 \%$ of $0.5 \mathrm{~mm}$. The results can be explained as follows. For the cladded building with one internal frame, the shear diaphragm panels at two sides of considered frame, also at the end bays, take a large fraction of load acting on the building and transfer to the gables. The remaining load is transferred to the internal frame. For the building having more than one internal frame, the shear diaphragm panels not at the end bays take lesser 
load, as opposed to end bay panels, and so more load is transferred to the considered frame.

As expected, serviceability under the wind load design cases is no longer the critical design constraint; the binding design constraint is combined bending and crushing of the web of the channel-section at the joints under the gravity load design case i.e., $\mathrm{g}_{6}=$ 0 . Also, for the cladding thickness of $0.5 \mathrm{~mm}$, these results suggest that the strength of the cladding may be considered critical in practice, i.e. $\mathrm{g}_{7} \cong 0$. For the cladding thickness of $0.7 \mathrm{~mm}$ the strength of the cladding would appear not to be binding in general.

\subsection{Frame spacing of $4 \mathrm{~m}$ : without stressed-skin action}

Table 7(a) summarises the results of the design optimization for both rigid and semi-rigid joints. Note that the total cost for the rigid joints is not available, because fabricating rigid cost is more complicated (Section 1) and is not factored into costs. However, Table 7(c) below shows that the optimized stressed-skin design based on a cladding thickness of $0.7 \mathrm{~mm}$ is more economical by far. As expected, for the semi-rigid joint, the critical constraint of the horizontal deflection at the eaves under SLC2 with WLC4 is binding, i.e. $\mathrm{g}_{8}=0$. For the rigid-joint, the constraint of lateral-torsional buckling controls the design, under the action of wind load (ULC2 with WLC4), i.e., $\mathrm{g}_{3}=$ -0.02 .

\subsection{Frame spacing of $4 \mathrm{~m}$ : with stressed-skin action}

In Section 5, the frame spacing and the number of internal frames are two independent variables. Table 7(b) and (c) summarises the results of the optimization with stressed-skin action included for cladding thicknesses of $0.5 \mathrm{~mm}$ and $0.7 \mathrm{~mm}$, respectively. Building lengths of 16,12 and $8 \mathrm{~m}$ that comprised of three, two and one internal frames respectively were considered. For the cladding thickness of $0.5 \mathrm{~mm}$ the 
strength of the cladding is binding. If section sizes from the rigid-joint design had therefore been adopted, the cladding would have failed. The decrease in the total cost between the building with three internal frames and the building with one internal frame is approximately $17 \%$.

The same trend, as obtained for the frame spacing of $6 \mathrm{~m}$, was observed on the different number of internal frames in cladded building. For the cladding thickness of 0.7 $\mathrm{mm}$, the decrease in the total cost between the building with three internal frames and the building with one internal frame is $36 \%$ approximately. This difference (36\%) is roughly similar to that of the case of the frame spacing of $6 \mathrm{~m}(31 \%)$. It should also be noted that for the frame spacing of $4 \mathrm{~m}$ the total costs for three, two and one internal frames are similar to those for the frame spacing of $6 \mathrm{~m}$. The ultimate limit state under the gravity load case is critical; the binding constraint is combined bending and crushing of the web of the channel-section at the joints, i.e. $\mathrm{g}_{6}=0$.

\section{Conclusions}

The influence of stressed-skin diaphragm action on the optimal design of the internal frame of a cold-formed steel portal framing system with semi-rigid joints has been investigated. Both ultimate and serviceability limit states were considered, using deflection limits recommended by The Steel Construction Institute (SCI). Wind load combinations were included. The genetic algorithm was adopted for the optimization process which shows the robustness and reliability in searching the most economical design of considered frame. A summary of all the results provided in Fig. 16.

It was shown that if stressed-skin action is included in the design, then for a building with two internal frames the cost of the frames can be reduced by around 53\%; this reduces to around $42 \%$ for a building with three internal frames. Furthermore, it was 
shown that the wind load design cases were no longer critical, with the binding constraint being the ultimate limit state under the gravity load case.

It was also shown for a building with three internal frames, that if the combined effect of both stressed-skin action and semi-rigidity of the joints are ignored, and the frame designed on the basis of a rigid joint assumption, that failure of the cladding system could occur before first yield of the frame.

The identified benefits of using stressed-skin action are significant. The potential savings are encouraging, but indicate a need for further studies as to when failure of the roofing could be an issue for designers when the frame is relatively flexible. BS 5950 was used in this research, as opposed to Eurocode 3 which is not yet mature. Future research will be to use Eurocode 3 for a comparison against BS 5950 and assist in the formulation of a transparent criterion for the ease of application in practical design with Eurocode 3. In addition, a study of the influence of joint stiffness on buckling length would be interesting for further research.

\section{Acknowledgement}

The financial support from the Queen's University Belfast is gratefully acknowledged.

\section{References}

[1] Kirk P. Design of a cold-formed section portal frame building system. In proceedings of the 8th International Specialty Conference on Cold-formed Steel Structures, 11-12 November 1986 St Louis. Missouri: University of Missouri-Rolla, 295-310.

[2] Phan DT, Lim JBP, Sha W, Siew C, Tanyimboh T, Issa H and Mohammad F. Design optimization of cold-formed steel portal frames taking into account the effect of topography. Engineering Optimization 2013; 45:415-33.

[3] Saka MP. Optimum design of pitched roof steel frames with haunched rafters by genetic algorithm. Computers and Structures 2003, 81, 1967-1978.

[4] Issa HK and Mohammad FA. Effect of mutation schemes on convergence to optimum design of steel frames. Journal of Constructional Steel Research 2010, 66(7), 954-961. 
[5] Phan DT, Lim JBP, Tanyimboh TT, Lawson RM, Martin S and Sha W. Effect of serviceability limit on optimal design of steel portal frames. Journal of Constructional Steel Research, 2013, 86, 74-84.

[6] Mosquera JC and Gargoum LA. A sequential algorithm for minimum weight design of 2-D steel portal frame using Eurocode 3. International Journal of Steel Structures 2014; 14(1), 141-149.

[7] Hernández S, Fontán A N, Perezzán J.C and Loscos, P. Design optimization of steel portal frames. Advances in Engineering Software 2005, 36, 626-633.

[8] Kravanja S, Turkalj G, Šilih S and Žula T. Optimal design of single-story steel building structures based on parametric MINLP optimization. Journal of Constructional Steel Research 2013, 81, 86-103.

[9] SCI Advisory Desk. AD-090: Deflection limits for pitched roof portal frames (Amended). Ascot: The Steel Construction Institute, 2010.

[10] Lim JBP and Nethercot DA. Stiffness prediction for bolted moment-connections between cold-formed steel members. Journal of Constructional and Steel Research 2004; 60:85-107.

[11] Lim JBP and Nethercot DA. Finite element idealization of a cold-formed steel portal frame. Journal of Structural Engineering, ASCE 2004; 130(1):78-94.

[12] Davies JM. Computer analysis of stressed-skin buildings. Civil Engineering and Public Works Review 1972; 1154-1157.

[13] British Standard. BS 5950: Structural use of steelworks in building. Part 9. Code of practice for stressed-skin design. London: British Standards Institution, 1994.

[14] Davies JM and Bryan ER. Manual of stressed skin diaphragm design. London: Granada, 1982.

[15] Bryan ER. The stressed-skin design of steel buildings. Department of Civil Engineering Report. University of Salford, 1971.

[16] Davies JM. The plastic collapse of framed structures clad with corrugated steel sheeting. ICE Proceedings, 1973; 55:23-42.

[17] Bates W, Bryan ER and El-dakhakhni WM. Full-scale tests on a portal frame shed. The Structural Engineer 1965; 43:199-208.

[18] Bryan ER and Mohsin M E. The design and testing of a steel building taking account of the sheeting. The International Association of Bridge and Structural Engineering, 9th Congress, Preliminary Report, Amsterdam, 1972; 305-314.

[19] Strnad M and Pirner M. Static and dynamic full-scale tests on a portal frame structure. The Structural Engineer, 1978; 56:45-52.

[20] Davies JM, Engel P, Liu TTC and Morris LJ. Realistic model of steel portal frame behavior. The Structural Engineer, 1990; 68(1):30-35.

[21] Heldt TJ and Mahendran M. Full scale experiments of a steel portal frame building. Journal of the Australian Steel Institute, Steel Construction, 1998; 32:3-21.

[22] Wrzesien AM, Lim JBP, Xu Y, Dundu M, Macleod I and Lawson RM. Stressed skin effects on cold-formed steel portal frames with semi-rigid joints - experimental study. The 6th International Conference on Coupled Instabilities in Metal Structures, Glasgow, 2012.

[23] Wrzesien AM, Lim JBP and Nethercot DA. Optimum joint detailed for a general coldformed steel portal frame. Advanced Structures Engineering, 2012; 15(9):1635-51.

[24] Davies JM and Lawson RM. Stressed skin action of modern steel roof systems. The Structural Engineer, 1999; 77(21):30-35. 
[25] British Standards. BS 6399: Loading for buildings. London: British Standards Institution, 2002.

[26] CSB. Purlins, rails and eaves beams. Cumbria: Steadmans and Son 2012.

[27] British Standards. BS 5950: Structural use of steelworks in building. Part 5. Code of practice for design of cold-formed thin gauge sections. London: British Standards Institution. London: British Standards Institution, 1998.

[28] CSB. Single skin system. Cumbria: Steadmans and Son 2012.

[29] British Standards. BS 5950: Structural use of steelworks in building. Part 1. Code of practice for design - Rolled and welded sections. London: British Standards Institution, 2001.

[30] Zandanfarrokh F and Bryan ER. Testing and design of bolted connections in cold-formed steel sections. In proceedings of the 11th International Specialty Conference on Coldformed Steel Structures, 20-21 October 1992 St Louis. Missouri: University of MissouriRolla, 625-662.

[31] ANSYS Inc. Programmer's manual for mechanical APDL. USA: SAS IP, 2009.

[32] Dubina D, Ungureanu V and Landolfo R. Design of cold-formed steel structures. Berlin: Wiley-Blackwell Inc, 2012.

[33] Deb K and Agrawal RB. Simulated binary crossover for continuous space. Complex Systems, 1995; 9(2):115-148.

[34] Deb K and Gulati S. Design of truss-structures for minimum weight using genetic algorithms. Finite Element in Analysis and Design, 2001; 37:447-465.

[35] Deb K. An efficient constraint handling method for genetic algorithms. Computer Methods in Applied Mechanics and Engineering, 2000; 186:311-338.

[36] Deb K. Multi-objective optimization using evolutionary algorithms. Chichester: John Wiley and Sons Inc, 2001.

[37] Camp C, Pezeshk S and Cao G. Optimum design of two dimensional structures using genetic algorithm. Journal of Structural Engineering, ASCE 1998; 124(5):551-559. 


\section{Table captions}

Table 1 Deflection limits for steel portal frames recommended by SCI [9]

Table 2 Dimensions and section properties of cold-formed steel channel sections Table 3 Parameters used in calculations of diaphragm roof characteristic

Table 4 Shear properties of panels (a) $6 \mathrm{~m}$ frame spacing; (b) $4 \mathrm{~m}$ frame spacing

Table 5 Mechanical properties of fasteners (after BS 5950-Part 9 Table 5 [13])

Table 6 Optimal solutions for frame spacing of $6 \mathrm{~m}$ (a) Stressed-skin action not considered; (b) Influence of stressed-skin action pertaining to cladding thickness of 0.5 $\mathrm{mm}$; (c) Influence of stressed-skin action pertaining to cladding thickness of $0.7 \mathrm{~mm}$

Table 7 Optimal solutions for frame spacing of $4 \mathrm{~m}$ (a) Stressed-skin action not considered; (b) Influence of stressed-skin action pertaining to cladding thickness of 0.5 $\mathrm{mm}$; (c) Influence of stressed-skin action pertaining to cladding thickness of $0.7 \mathrm{~mm}$ 


\section{Figure captions}

Fig. 1 Details of joints for cold-formed steel portal framing system

(a) Eaves joint with swages [1]

(b) Eaves joint without swages

(c) Apex joint without swages

Fig. 2 Area on floor of building to define unit cost within frame spacing

Fig. 3 Details of bolt-group resisting moment

Fig. 4 Free body diagram of channel-section when joint is in pure bending

(a) Details of typical channel-section and bolt-group

(b) Free body diagram

Fig. 5 Stressed-skin action in buildings (after BS 5950-Part 9 [13])

(a) Stressed-skin action under horizontal loads

(b) Stressed-skin action under vertical loads

Fig. 6 Geometry of internal frame of building (position of purlins and side rails also shown)

Fig. 7 Plan view of buildings considered to investigate the effect of stressed-skin action (a) Building A; (b) Building B; (c) Building C; (d) Building D; (e) Building E; (f) Building $\mathrm{F}$

Fig. 8 Details of back-to-back cold-formed steel channel-sections

Fig. 9 Fastener arrangement of the roof diaphragm 6.09/6/0.7 for internal frame

Fig. 10 Wind load cases (a) WLC1; (b) WLC2; (c) WLC3; (d) WLC4; (e) WLC5; (f) WLC6

Fig. 11 Frame analysis model of building having two internal frames (lateral restraints provided by purlin and side rails not shown)

Fig. 12 Parameters used to define semi-rigid joints of internal frame

Fig. 13 Brackets and bolt-group sizes (a) Eaves joint; (b) Apex joint

Fig. 14 Flowchart of real-coded niching genetic algorithm (RC-NGA)

Fig. 15 Convergence history for a sample optimization run

Fig. 16 3D-bar chart of material unit cost of internal frame 
TABLES

Table 1 Deflection limits for steel portal frames recommended by SCI [9]

\begin{tabular}{|c|c|c|}
\hline & $\begin{array}{c}\text { Absolute } \\
\text { deflection }\end{array}$ & $\begin{array}{c}\text { Differential } \\
\text { deflection } \\
\text { relative to } \\
\text { adjacent frame }\end{array}$ \\
\hline $\begin{array}{c}\text { Lateral deflection } \\
\text { at eaves }\end{array}$ & $\leq \frac{\mathrm{h}_{\mathrm{f}}}{100}$ & $\leq \frac{\mathrm{b}_{\mathrm{f}}}{200}$ \\
\hline $\begin{array}{c}\text { Vertical deflection } \\
\text { at apex }\end{array}$ & - & $\leq \frac{\mathrm{b}_{\mathrm{f}}}{100}$ \\
\hline
\end{tabular}

Table 2 Dimensions and section properties of cold-formed steel channel sections

\begin{tabular}{|c|c|c|c|c|c|c|c|c|c|c|}
\hline № & Section & $\begin{array}{c}\mathrm{D} \\
(\mathrm{mm})\end{array}$ & $\begin{array}{c}\mathrm{B} \\
(\mathrm{mm})\end{array}$ & $\begin{array}{c}\mathrm{t} \\
(\mathrm{mm})\end{array}$ & $\begin{array}{c}\mathrm{EA}\left(\mathrm{x} 10^{2}\right) \\
(\mathrm{kN})\end{array}$ & $\begin{array}{c}\mathrm{EI}\left(\mathrm{x} 10^{6}\right) \\
\left(\mathrm{kN} \cdot \mathrm{mm}^{2}\right)\end{array}$ & $\begin{array}{c}\mathrm{M}_{\mathrm{c}} \\
(\mathrm{kNm})\end{array}$ & $\begin{array}{c}\mathrm{k}_{\mathrm{b}}{ }^{*} \\
(\mathrm{kN} / \mathrm{mm})\end{array}$ & $\begin{array}{l}\text { Weight } \\
(\mathrm{kg} / \mathrm{m})\end{array}$ & $\begin{array}{l}\text { Cost } \\
(£ / m)\end{array}$ \\
\hline 1 & C15014 & 152 & 64 & 1.4 & 858.95 & 314.47 & 6.49 & 4.72 & 3.29 & 4.04 \\
\hline 2 & C15016 & 52 & 64 & 1.6 & 981.95 & 5.91 & 7.91 & 5.27 & 3.76 & .23 \\
\hline 3 & 5018 & 2 & 64 & 1.8 & 1100.85 & $\overline{775}$ & 9.24 & 5.81 & .21 & .74 \\
\hline 4 & 5020 & 52 & 64 & 2.0 & 19.75 & 439.52 & 10.48 & 6.32 & 4.67 & 5.19 \\
\hline 5 & 20015 & 203 & 76 & $1 .$. & 45.95 & 733.08 & 10.29 & 5.0 & 4.38 & 5.02 \\
\hline 6 & 20016 & 203 & 76 & 1.6 & 1221.80 & 780.03 & 11.44 & 5.27 & 4.67 & 5.31 \\
\hline 7 & 20018 & 203 & 76 & 1.8 & 1371.45 & 872.89 & 13.74 & 5.8 & 5.25 & 5.98 \\
\hline 8 & 200 & 203 & 76 & 20 & 1521.10 & 964.16 & 15.93 & 6.32 & 5.82 & 6.56 \\
\hline 9 & 5 & 203 & 76 & 77 & 55 & 31 & 20.96 & 7.5 & 7.23 & 12 \\
\hline 10 & 25018 & 2 & 76 & 18, & 55 & 52 & 17.36 & 5.8 & 5.96 & 7.00 \\
\hline 11 & 5 & 2 & 76 & $2 .(1$ & 0 & 21 & 20.26 & 6. & 6.61 & 7.95 \\
\hline 12 & $\mathrm{C} 25025$ & 254 & 76 & 2.5 & 2144.30 & 10.85 & 27.03 & 7.5 & 8.21 & 9.88 \\
\hline 13 & $\mathrm{C} 25030$ & 254 & 76 & 3.0 & 2556.35 & 2374.11 & 33.35 & 8.57 & 9.79 & 11.82 \\
\hline 14 & C30025 & 300 & 95 & 2.5 & 2558.40 & 3400.54 & 36.42 & 7.50 & 9.80 & 11.18 \\
\hline 15 & C30030 & 300 & 95 & 3 & 305 & 4027.64 & 46.01 & 8.57 & 11.69 & 13.04 \\
\hline 16 & & 400 & 100 & & & 22 & 50.02 & 7.5 & 11.96 & 17.52 \\
\hline 17 & $\mathrm{C} 40030$ & 400 & 100 & 3.0 & 3733.05 & 8296.35 & 65.09 & 8.57 & 14.29 & 21.74 \\
\hline \multicolumn{11}{|c|}{$\begin{array}{l}\text { * Values for } \mathrm{k}_{\mathrm{b}} \text { calculated pertain to a single channel connected to a bracket of } 3 \mathrm{~mm} \text {, in accordance with } \\
\text { design expressions provided by Zadanfarrokh and Bryan [30]: } \\
\mathrm{c}_{\mathrm{zad}}=25\left(10 / \mathrm{t}_{1}+10 / \mathrm{t}_{2}-2\right) 10^{-3}(\mathrm{~mm} / \mathrm{kN}) \\
\mathrm{k}_{\mathrm{b}}=1 / \mathrm{c}_{\mathrm{zad}}\end{array}$} \\
\hline
\end{tabular}


Table 3 Parameters used in calculations of diaphragm roof characteristic

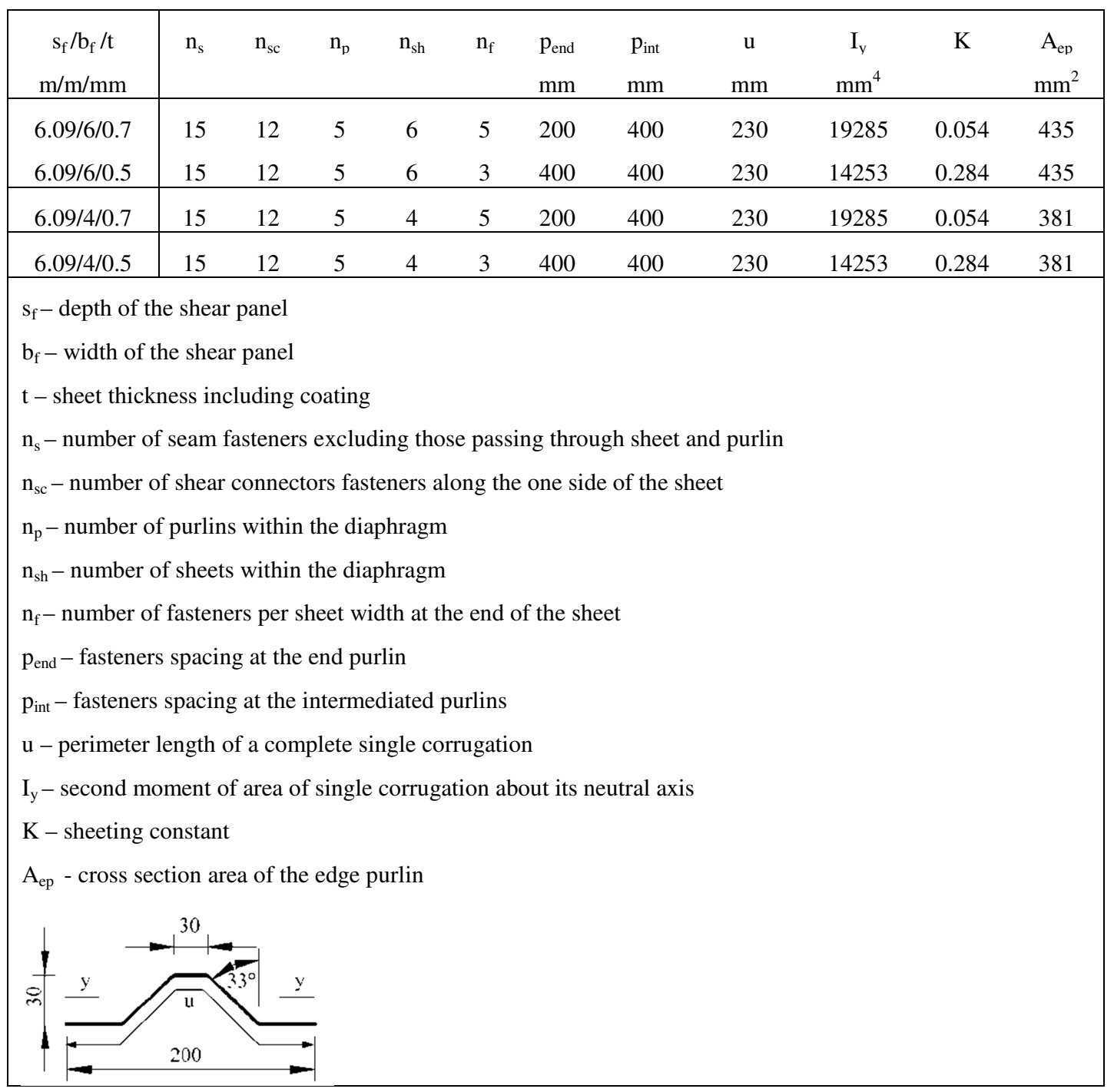


Table 4 Shear properties of panels

(a) $6 \mathrm{~m}$ frame spacing

\begin{tabular}{|c|c|c|c|}
\hline $\begin{array}{c}\text { Cladding } \\
\text { thickness } \\
(\mathrm{mm})\end{array}$ & $\begin{array}{c}\text { Number of } \\
\text { internal frames }\end{array}$ & $\begin{array}{c}\text { Panel } \\
\text { designation } \\
\mathrm{s}_{\mathrm{f}} / \mathrm{b}_{\mathrm{f}} / \mathrm{t}\end{array}$ & $\begin{array}{c}\text { Equivalent } \\
\text { diagonal stiffness } \\
\mathrm{k}_{\mathrm{s}}(\mathrm{kN} / \mathrm{mm})\end{array}$ \\
\hline 0.5 & 3 & $6.09 / 6 / 0.5$ & 2.207 \\
\hline 0.5 & 2 & $6.09 / 6 / 0.5$ & 2.317 \\
\hline 0.5 & 1 & $6.09 / 6 / 0.5$ & 2.347 \\
\hline 0.7 & 3 & $6.09 / 6 / 0.7$ & 5.315 \\
\hline 0.7 & 2 & $6.09 / 6 / 0.7$ & 6.001 \\
\hline 0.7 & 1 & $6.09 / 6 / 0.7$ & 6.200 \\
\hline
\end{tabular}

(b) $4 \mathrm{~m}$ frame spacing

\begin{tabular}{|c|c|c|c|}
\hline $\begin{array}{c}\text { Cladding } \\
\text { thickness } \\
(\mathrm{mm})\end{array}$ & $\begin{array}{c}\text { Number of } \\
\text { internal frames }\end{array}$ & $\begin{array}{c}\text { Panel } \\
\text { designation } \\
\mathrm{s}_{\mathrm{f}} / \mathrm{b}_{\mathrm{f}} / \mathrm{t}\end{array}$ & $\begin{array}{c}\text { Equivalent } \\
\text { diagonal stiffness } \\
\mathrm{k}_{\mathrm{s}}(\mathrm{kN} / \mathrm{mm})\end{array}$ \\
\hline 0.5 & 3 & $6.09 / 4 / 0.5$ & 2.597 \\
\hline 0.5 & 2 & $6.09 / 4 / 0.5$ & 2.616 \\
\hline 0.5 & 1 & $6.09 / 4 / 0.5$ & 2.537 \\
\hline 0.7 & 3 & $6.09 / 4 / 0.7$ & 7.031 \\
\hline 0.7 & 2 & $6.09 / 4 / 0.7$ & 7.165 \\
\hline 0.7 & 1 & $6.09 / 4 / 0.7$ & 6.607 \\
\hline
\end{tabular}

Table 5 Mechanical properties of fasteners (after BS 5950-Part 9 Table 5 [13])

\begin{tabular}{|c|c|c|}
\hline Fastener type & $\begin{array}{c}\text { Design resistance / } \\
\text { sheet thickness }\end{array}$ & Slip \\
\hline $\begin{array}{c}\mathrm{F} \\
(\mathrm{kN} / \mathrm{mm})\end{array}$ & 0.35 \\
$\begin{array}{c}\text { washer (sheet fasteners) } \\
6.3 \mathrm{~mm} / \mathrm{kN})\end{array}$ \\
$\begin{array}{c}\text { mm diameter screws + neoprene } \\
\text { washer (seam and shear connector fastener) }\end{array}$ & 5.72 & 0.35 \\
\hline
\end{tabular}

* values calculated for design yield strength of cladding of 390MPa 
Table 6 Optimal solutions for frame spacing of $6 \mathrm{~m}$

(a) Stressed-skin action not considered

\begin{tabular}{|c|c|c|c|c|c|c|c|}
\hline & \multicolumn{2}{|c|}{$\begin{array}{c}\text { Gravity load design } \\
\text { constraints }\end{array}$} & \multicolumn{2}{|c|}{$\begin{array}{l}\text { Wind load design } \\
\text { constraints }\end{array}$} & \multirow{2}{*}{$\begin{array}{l}\text { Cost of } \\
\text { material } \\
\text { for column } \\
\text { and rafters } \\
\left(£ / \mathrm{m}^{2}\right)\end{array}$} & \multirow{2}{*}{$\begin{array}{c}\text { Cost of } \\
\text { material } \\
\text { for joints } \\
\left(\mathfrak{f} / \mathrm{m}^{2}\right)\end{array}$} & \multirow[t]{2}{*}{$\begin{array}{l}\text { Total cost } \\
\left(£ / \mathrm{m}^{2}\right)\end{array}$} \\
\hline & ULS & SLS & ULS & SLS & & & \\
\hline Rigid joints & $\mathrm{g}_{2}=-0.24$ & $\begin{array}{l}\mathrm{g}_{8}=-0.87 \\
\mathrm{~g}_{9}=-0.62\end{array}$ & $\mathrm{~g}_{2}=-0.16$ & $\begin{array}{l}\mathrm{g}_{8}=-0.21 \\
\mathrm{~g}_{9}=-0.66\end{array}$ & 6.60 & - & - \\
\hline $\begin{array}{l}\text { Semi-rigid } \\
\text { joints }\end{array}$ & $\mathrm{g}_{6}=-0.12$ & $\begin{array}{l}g_{8}=-0.90 \\
g_{9}=-0.69\end{array}$ & $g_{6}=-0.07$ & $\begin{array}{c}\mathrm{g}_{8}=0 \\
\mathrm{~g}_{9}=-0.89\end{array}$ & 6.60 & 0.51 & 7.11 \\
\hline
\end{tabular}

(b) Influence of stressed-skin action pertaining to cladding thickness of $0.5 \mathrm{~mm}$

\begin{tabular}{|c|c|c|c|c|c|c|c|}
\hline \multirow{2}{*}{$\begin{array}{l}\text { Number } \\
\text { of } \\
\text { internal } \\
\text { frames } \\
\text { (Building } \\
\text { length) }\end{array}$} & \multicolumn{2}{|c|}{$\begin{array}{l}\text { Gravity load design } \\
\text { constraints }\end{array}$} & \multicolumn{2}{|c|}{$\begin{array}{l}\text { Wind load design } \\
\text { constraints }\end{array}$} & \multirow{2}{*}{$\begin{array}{l}\text { Cost of } \\
\text { material } \\
\text { for column } \\
\text { and rafters } \\
\quad\left(£ / \mathrm{m}^{2}\right)\end{array}$} & \multirow{2}{*}{$\begin{array}{l}\text { Cost of } \\
\text { material } \\
\text { for joints } \\
\left(£ / \mathrm{m}^{2}\right)\end{array}$} & \multirow[t]{2}{*}{$\begin{array}{l}\text { Total cost } \\
\left(£ / \mathrm{m}^{2}\right)\end{array}$} \\
\hline & ULS & SLS & ULS & SLS & & & \\
\hline $\begin{array}{c}3 \\
(24 \mathrm{~m})\end{array}$ & $\begin{array}{c}\mathrm{g}_{3}=-0.07 \\
\mathrm{~g}_{6}=0{ }^{*} \\
\mathrm{~g}_{7}=-0.06\end{array}$ & $\begin{array}{l}\mathrm{g}_{8}=-0.75 \\
\mathrm{~g}_{9}=-0.27 \\
\mathrm{~g}_{10}=-0.19\end{array}$ & $\begin{array}{l}\mathrm{g}_{3}=-0.25 \\
\mathrm{~g}_{6}=-0.22 \\
\mathrm{~g}_{7}=-0.65\end{array}$ & $\begin{array}{l}\mathrm{g}_{8}=-0.93 \\
\mathrm{~g}_{9}=-0.85 \\
\mathrm{~g}_{10}=-0.07\end{array}$ & 5.95 & 0.52 & 6.47 \\
\hline $\begin{array}{c}2 \\
(18 \mathrm{~m})\end{array}$ & $\begin{array}{c}\mathrm{g}_{3}=-0.10 \\
\mathrm{~g}_{6}=0 * * \\
\mathrm{~g}_{7}=0\end{array}$ & $\begin{array}{l}\mathrm{g}_{8}=-0.78 \\
\mathrm{~g}_{9}=-0.35 \\
\mathrm{~g}_{10}=-0.14\end{array}$ & $\begin{array}{l}\mathrm{g}_{3}=-0.29 \\
\mathrm{~g}_{6}=-0.25 \\
\mathrm{~g}_{7}=-0.70\end{array}$ & $\begin{array}{l}\mathrm{g}_{8}=-0.96 \\
\mathrm{~g}_{9}=-0.92 \\
\mathrm{~g}_{10}=-0.10\end{array}$ & 5.65 & 0.58 & 6.23 \\
\hline $\begin{array}{c}1 \\
(12 \mathrm{~m})\end{array}$ & $\begin{array}{c}\mathrm{g}_{3}=-0.02 \\
\mathrm{~g}_{6}=0 \\
\mathrm{~g}_{7}=-0.03\end{array}$ & $\begin{array}{l}\mathrm{g}_{8}=-0.79 \\
\mathrm{~g}_{9}=-0.38 \\
\mathrm{~g}_{10}=-0.21\end{array}$ & $\begin{array}{l}\mathrm{g}_{3}=-0.26 \\
\mathrm{~g}_{6}=-0.20 \\
\mathrm{~g}_{7}=-0.50\end{array}$ & $\begin{array}{l}\mathrm{g}_{8}=-0.91 \\
\mathrm{~g}_{9}=-0.89 \\
\mathrm{~g}_{10}=-0.12\end{array}$ & 5.42 & 0.61 & 6.03 \\
\hline
\end{tabular}

\footnotetext{
* Rafter at apex
}

** Column at eaves 
(c) Influence of stressed-skin action pertaining to cladding thickness of $0.7 \mathrm{~mm}$

\begin{tabular}{|c|c|c|c|c|c|c|c|}
\hline \multirow{2}{*}{$\begin{array}{c}\text { Number } \\
\text { of } \\
\text { internal } \\
\text { frames } \\
\text { (Building } \\
\text { length) }\end{array}$} & \multicolumn{2}{|c|}{$\begin{array}{l}\text { Gravity load design } \\
\text { constraints }\end{array}$} & \multicolumn{2}{|c|}{$\begin{array}{l}\text { Wind load design } \\
\text { constraints }\end{array}$} & \multirow{2}{*}{$\begin{array}{l}\text { Cost of } \\
\text { material } \\
\text { for column } \\
\text { and rafters } \\
\left(£ / \mathrm{m}^{2}\right)\end{array}$} & \multirow{2}{*}{$\begin{array}{c}\text { Cost of } \\
\text { material } \\
\text { for joints } \\
\left(£ / \mathrm{m}^{2}\right)\end{array}$} & \multirow[t]{2}{*}{$\begin{array}{l}\text { Total cost } \\
\left(£ / \mathrm{m}^{2}\right)\end{array}$} \\
\hline & ULS & SLS & ULS & SLS & & & \\
\hline \multirow{3}{*}{$\begin{array}{c}3 \\
(24 \mathrm{~m})\end{array}$} & $\mathrm{g}_{3}=-0.10$ & $\mathrm{~g}_{8}=-0.73$ & $\mathrm{~g}_{3}=-0.15$ & $\mathrm{~g}_{8}=-0.89$ & \multirow{3}{*}{5.75} & \multirow{3}{*}{0.52} & \multirow{3}{*}{6.27} \\
\hline & $\mathrm{g}_{6}=0 *$ & $\mathrm{~g}_{9}=-0.20$ & $\mathrm{~g}_{6}=-0.10$ & $\mathrm{~g}_{9}=-0.80$ & & & \\
\hline & $\mathrm{g}_{7}=-0.38$ & $\mathrm{~g}_{10}=-0.48$ & $\mathrm{~g}_{7}=-0.54$ & $\mathrm{~g}_{10}=-0.19$ & & & \\
\hline \multirow{3}{*}{$\begin{array}{c}2 \\
(18 \mathrm{~m})\end{array}$} & $\mathrm{g}_{3}=-0.04$ & $\mathrm{~g}_{8}=-0.78$ & $\mathrm{~g}_{3}=-0.18$ & $\mathrm{~g}_{8}=-0.91$ & \multirow{3}{*}{4.98} & \multirow{3}{*}{0.55} & \multirow{3}{*}{5.53} \\
\hline & $\mathrm{g}_{6}=0^{* * *}$ & $\mathrm{~g}_{9}=-0.30$ & $\mathrm{~g}_{6}=-0.11$ & $\mathrm{~g}_{9}=-0.85$ & & & \\
\hline & $\mathrm{g}_{7}=-0.23$ & $\mathrm{~g}_{10}=-0.30$ & $\mathrm{~g}_{7}=-0.55$ & $\mathrm{~g}_{10}=-0.21$ & & & \\
\hline \multirow{3}{*}{$\begin{array}{c}1 \\
(12 \mathrm{~m})\end{array}$} & $\mathrm{g}_{3}=-0.08$ & $\mathrm{~g}_{8}=-0.78$ & $\mathrm{~g}_{3}=-0.30$ & $\mathrm{~g}_{8}=-0.87$ & \multirow{3}{*}{3.78} & \multirow{3}{*}{0.54} & \multirow{3}{*}{4.32} \\
\hline & $\mathrm{g}_{6}=0^{* *}$ & $\mathrm{~g}_{9}=-0.30$ & $\mathrm{~g}_{6}=-0.05$ & $\mathrm{~g}_{9}=-0.81$ & & & \\
\hline & $\mathrm{g}_{7}=-0.26$ & $\mathrm{~g}_{10}=-0.30$ & $\mathrm{~g}_{7}=-0.55$ & $\mathrm{~g}_{10}=-0.22$ & & & \\
\hline
\end{tabular}

* Column at eaves

${ }^{* *}$ Rafter at eaves 
Table 7 Optimal solutions for frame spacing of $4 \mathrm{~m}$

(a) Stressed-skin action not considered

\begin{tabular}{|c|c|c|c|c|c|c|c|}
\hline & \multicolumn{2}{|c|}{$\begin{array}{c}\text { Gravity load design } \\
\text { constraints }\end{array}$} & \multicolumn{2}{|c|}{$\begin{array}{l}\text { Wind load design } \\
\text { constraints }\end{array}$} & \multirow{2}{*}{$\begin{array}{l}\text { Cost of } \\
\text { material } \\
\text { for column } \\
\text { and rafters } \\
\left(£ / \mathrm{m}^{2}\right)\end{array}$} & \multirow{2}{*}{$\begin{array}{l}\text { Cost of } \\
\text { material } \\
\text { for joints } \\
\left(£ / \mathrm{m}^{2}\right)\end{array}$} & \multirow[t]{2}{*}{$\begin{array}{l}\text { Total cost } \\
\qquad\left(£ / \mathrm{m}^{2}\right)\end{array}$} \\
\hline & ULS & SLS & ULS & SLS & & & \\
\hline Rigid joints & $\mathrm{g}_{3}=-0.12$ & $\begin{array}{l}g_{8}=-0.75 \\
g_{9}=-0.26\end{array}$ & $\mathrm{~g}_{3}=-0.02$ & $\begin{array}{l}g_{8}=-0.08 \\
g_{9}=-0.60\end{array}$ & 7.81 & - & - \\
\hline $\begin{array}{l}\text { Semi-rigid } \\
\text { joints }\end{array}$ & $\mathrm{g}_{3}=-0.49$ & $\begin{array}{l}\mathrm{g}_{8}=-0.76 \\
\mathrm{~g}_{9}=-0.32\end{array}$ & $\mathrm{~g}_{2}=-0.44$ & $\begin{array}{c}\mathrm{g}_{8}=0 \\
\mathrm{~g}_{9}=-0.89\end{array}$ & 9.88 & 0.84 & 10.72 \\
\hline
\end{tabular}

(b) Influence of stressed-skin action pertaining to cladding thickness of $0.5 \mathrm{~mm}$

\begin{tabular}{|c|c|c|c|c|c|c|c|}
\hline \multirow{2}{*}{$\begin{array}{c}\text { Number } \\
\text { of } \\
\text { internal } \\
\text { frames } \\
\text { (Building } \\
\text { length) }\end{array}$} & \multicolumn{2}{|c|}{$\begin{array}{l}\text { Gravity load design } \\
\text { constraints }\end{array}$} & \multicolumn{2}{|c|}{$\begin{array}{l}\text { Wind load design } \\
\text { constraints }\end{array}$} & \multirow{2}{*}{$\begin{array}{l}\text { Cost of } \\
\text { material } \\
\text { for column } \\
\text { and rafters } \\
\quad\left(£ / \mathrm{m}^{2}\right)\end{array}$} & \multirow{2}{*}{$\begin{array}{c}\text { Cost of } \\
\text { material } \\
\text { for joints } \\
\left(£ / \mathrm{m}^{2}\right)\end{array}$} & \multirow[t]{2}{*}{$\begin{array}{l}\text { Total cost } \\
\left(£ / \mathrm{m}^{2}\right)\end{array}$} \\
\hline & ULS & SLS & ULS & SLS & & & \\
\hline \multirow{3}{*}{$\begin{array}{c}3 \\
(16 \mathrm{~m})\end{array}$} & $\mathrm{g}_{3}=-0.44$ & $\mathrm{~g}_{8}=-0.75$ & $\mathrm{~g}_{3}=-0.51$ & $\mathrm{~g}_{8}=-0.86$ & \multirow{3}{*}{8.46} & \multirow{3}{*}{0.75} & \multirow{3}{*}{9.21} \\
\hline & $\mathrm{g}_{6}=-0.20$ & $\mathrm{~g}_{9}=-0.28$ & $\mathrm{~g}_{6}=-0.54$ & $\mathrm{~g}_{9}=-0.85$ & & & \\
\hline & $\mathrm{g}_{7}=0$ & $\mathrm{~g}_{10}=-0.14$ & $\mathrm{~g}_{7}=-0.50$ & $\mathrm{~g}_{10}=-0.09$ & & & \\
\hline \multirow{3}{*}{$\begin{array}{c}2 \\
(12 \mathrm{~m})\end{array}$} & $\mathrm{g}_{3}=-0.27$ & $\mathrm{~g}_{8}=-0.78$ & $\mathrm{~g}_{3}=-0.50$ & $\mathrm{~g}_{8}=-0.83$ & \multirow{3}{*}{7.81} & \multirow{3}{*}{0.96} & \multirow{3}{*}{8.77} \\
\hline & $\mathrm{g}_{6}=-0.39$ & $\mathrm{~g}_{9}=-0.26$ & $\mathrm{~g}_{6}=-0.55$ & $\mathrm{~g}_{9}=-0.90$ & & & \\
\hline & $\mathrm{g}_{7}=0$ & $g_{10}=-0.14$ & $\mathrm{~g}_{7}=-0.54$ & $\mathrm{~g}_{10}=-0.12$ & & & \\
\hline \multirow{3}{*}{$\begin{array}{c}1 \\
(8 \mathrm{~m})\end{array}$} & $\mathrm{g}_{3}=-0.15$ & $\mathrm{~g}_{8}=-0.78$ & $\mathrm{~g}_{3}=-0.30$ & $\mathrm{~g}_{8}=-0.87$ & \multirow{3}{*}{6.80} & \multirow{3}{*}{0.81} & \multirow{3}{*}{7.61} \\
\hline & $\mathrm{g}_{6}=-0.2$ & $\mathrm{~g}_{9}=-0.34$ & $\mathrm{~g}_{6}=-0.26$ & $\mathrm{~g}_{9}=-0.81$ & & & \\
\hline & $\mathrm{g}_{7}=0$ & $\mathrm{~g}_{10}=-0.14$ & $\mathrm{~g}_{7}=-0.36$ & $\mathrm{~g}_{10}=-0.11$ & & & \\
\hline
\end{tabular}


(c) Influence of stressed-skin action pertaining to cladding thickness of $0.7 \mathrm{~mm}$

\begin{tabular}{|c|c|c|c|c|c|c|c|}
\hline \multirow{2}{*}{$\begin{array}{c}\text { Number } \\
\text { of } \\
\text { internal } \\
\text { frames } \\
\text { (Building } \\
\text { length) }\end{array}$} & \multicolumn{2}{|c|}{$\begin{array}{c}\text { Gravity load design } \\
\text { constraints }\end{array}$} & \multicolumn{2}{|c|}{$\begin{array}{l}\text { Wind load design } \\
\text { constraints }\end{array}$} & \multirow{2}{*}{$\begin{array}{l}\text { Cost of } \\
\text { material } \\
\text { for column } \\
\text { and rafters } \\
\quad\left(£ / \mathrm{m}^{2}\right)\end{array}$} & \multirow{2}{*}{$\begin{array}{c}\text { Cost of } \\
\text { material } \\
\text { for joints } \\
\left(\mathfrak{f} / \mathrm{m}^{2}\right)\end{array}$} & \multirow[t]{2}{*}{$\begin{array}{l}\text { Total cost } \\
\left(£ / \mathrm{m}^{2}\right)\end{array}$} \\
\hline & ULS & SLS & ULS & SLS & & & \\
\hline \multirow{3}{*}{$\begin{array}{c}3 \\
(16 \mathrm{~m})\end{array}$} & $\mathrm{g}_{3}=-0.04$ & $\mathrm{~g}_{8}=-0.66$ & $\mathrm{~g}_{3}=-0.43$ & $\mathrm{~g}_{8}=-0.86$ & \multirow{3}{*}{5.78} & \multirow{3}{*}{0.86} & \multirow{3}{*}{6.64} \\
\hline & $\mathrm{g}_{6}=0^{*}$ & $\mathrm{~g}_{9}=-0.01$ & $\mathrm{~g}_{6}=-0.01$ & $\mathrm{~g}_{9}=-0.85$ & & & \\
\hline & $\mathrm{g}_{7}=-0.17$ & $\mathrm{~g}_{10}=-0.22$ & $\mathrm{~g}_{7}=-0.50$ & $\mathrm{~g}_{10}=-0.21$ & & & \\
\hline \multirow{3}{*}{$\begin{array}{c}2 \\
(12 \mathrm{~m})\end{array}$} & $\mathrm{g}_{3}=-0.15$ & $\mathrm{~g}_{8}=-0.70$ & $\mathrm{~g}_{3}=-0.45$ & $\mathrm{~g}_{8}=-0.83$ & \multirow{3}{*}{4.67} & \multirow{3}{*}{0.54} & \multirow{3}{*}{5.21} \\
\hline & $\mathrm{g}_{6}=0^{*}$ & $\mathrm{~g}_{9}=-0.07$ & $\mathrm{~g}_{6}=0$ & $\mathrm{~g}_{9}=-0.90$ & & & \\
\hline & $\mathrm{g}_{7}=-0.02$ & $\mathrm{~g}_{10}=-0.05$ & $\mathrm{~g}_{7}=-0.28$ & $\mathrm{~g}_{10}=-0.21$ & & & \\
\hline \multirow{3}{*}{$\begin{array}{c}1 \\
(8 \mathrm{~m})\end{array}$} & $\mathrm{g}_{3}=-0.04$ & $\mathrm{~g}_{8}=-0.79$ & $\mathrm{~g}_{3}=-0.31$ & $\mathrm{~g}_{8}=-0.87$ & \multirow{3}{*}{3.85} & \multirow{3}{*}{0.37} & \multirow{3}{*}{4.22} \\
\hline & $\mathrm{g}_{6}=0 *$ & $\mathrm{~g}_{9}=-0.26$ & $\mathrm{~g}_{6}=-0.01$ & $\mathrm{~g}_{9}=-0.81$ & & & \\
\hline & $\mathrm{g}_{7}=-0.35$ & $\mathrm{~g}_{10}=-0.41$ & $\mathrm{~g}_{7}=-0.54$ & $\mathrm{~g}_{10}=-0.23$ & & & \\
\hline
\end{tabular}

Column at eaves 


\section{FIGURES}

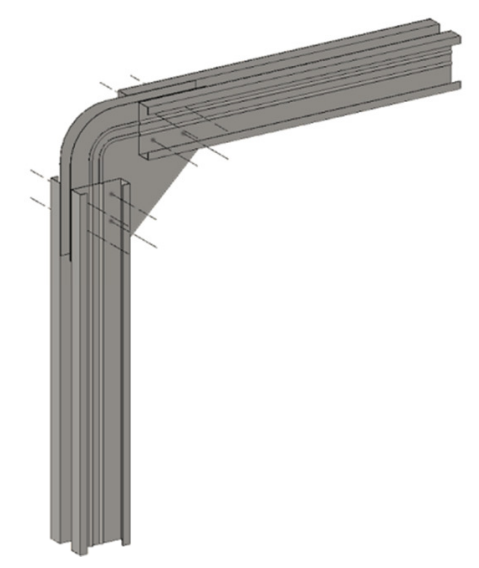

(a) Eaves joint with swages [1]

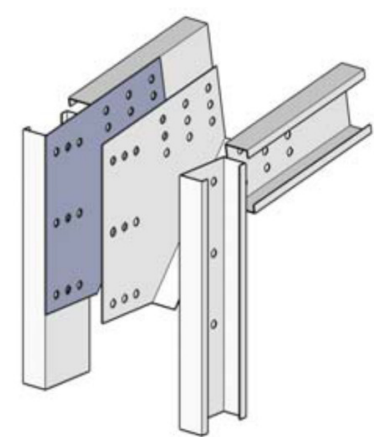

(b) Eaves joint without swages

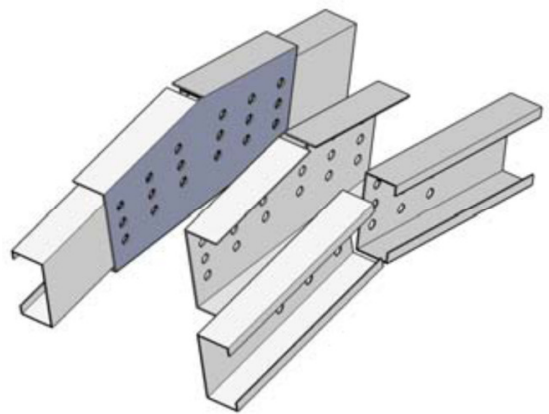

(c) Apex joint without swages

Figure 1: Details of joints for cold-formed steel portal framing system

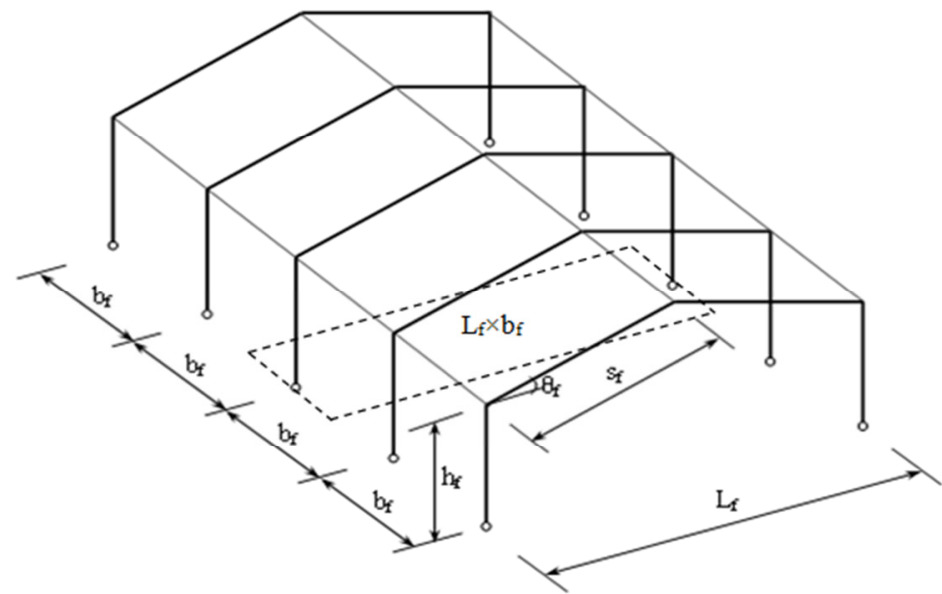

Figure 2: Area on floor of building to define unit cost within frame spacing 

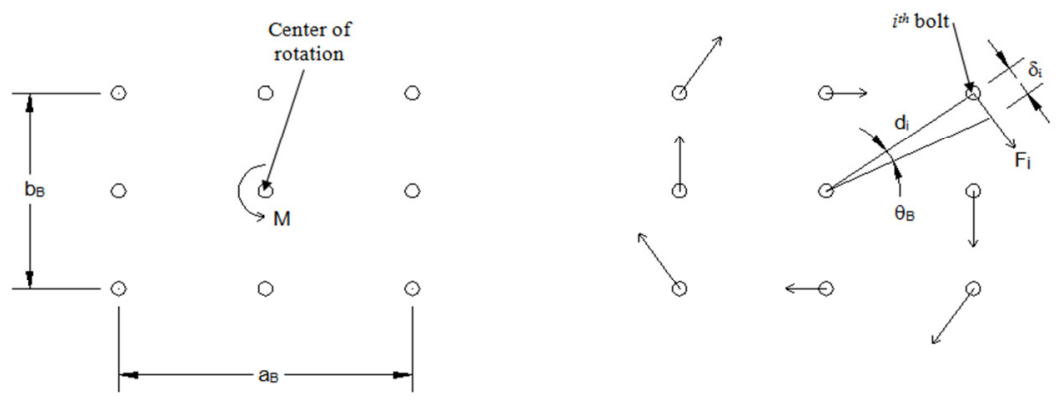

Figure 3: Details of bolt-group resisting moment

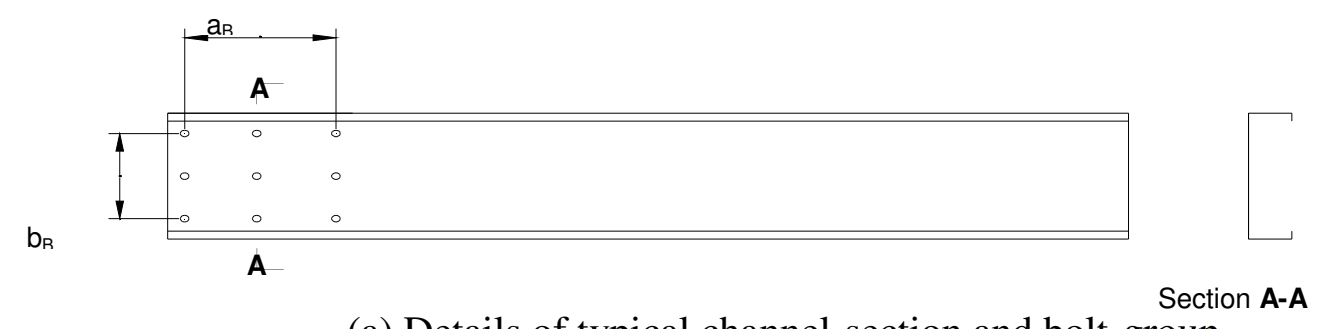

(a) Details of typical channel-section and bolt-group

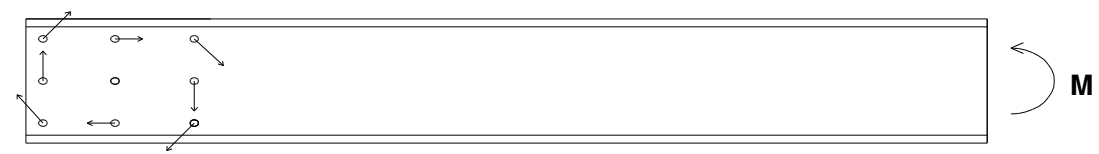

(b) Free body diagram

Figure 4: Free body diagram of channel-section when joint is in pure bending 


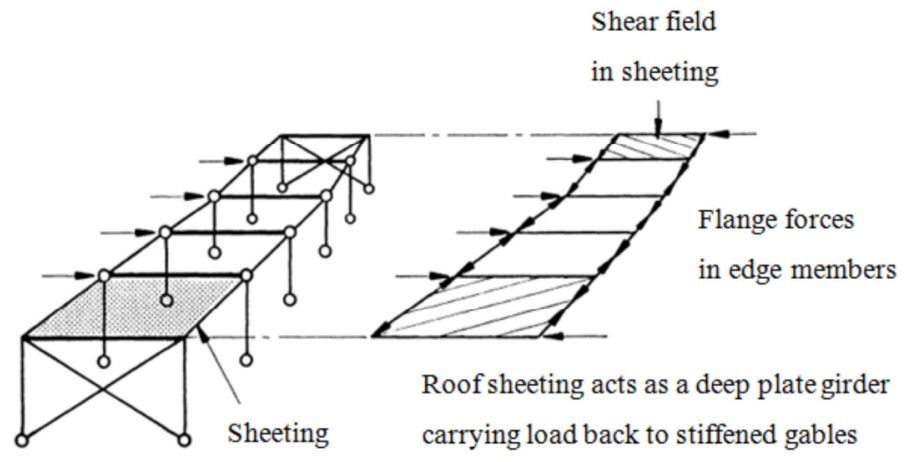

(a) Stressed-skin action under horizontal loads

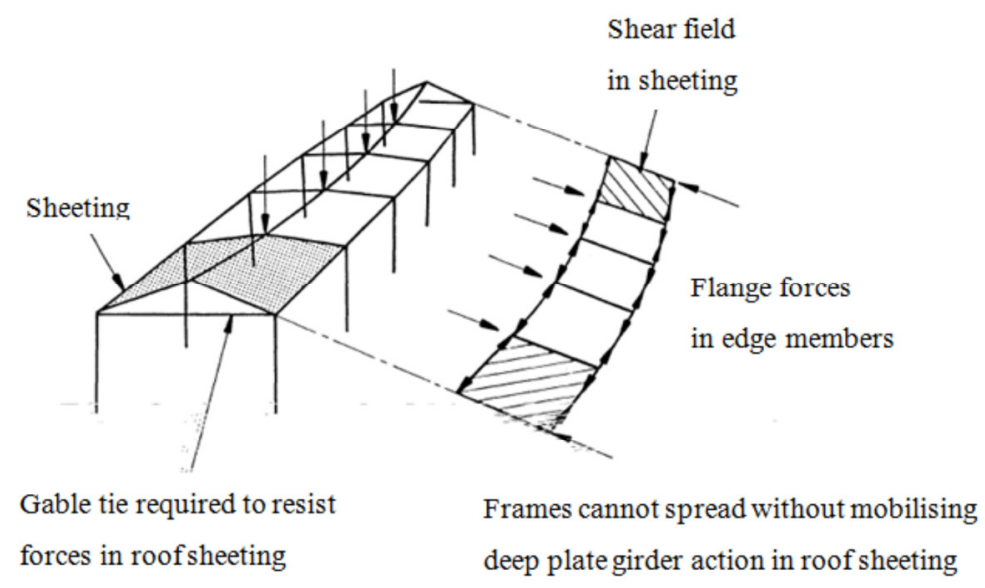

(b) Stressed-skin action under vertical loads

Figure 5: Stressed-skin action in buildings (after BS 5950-Part 9 [13])

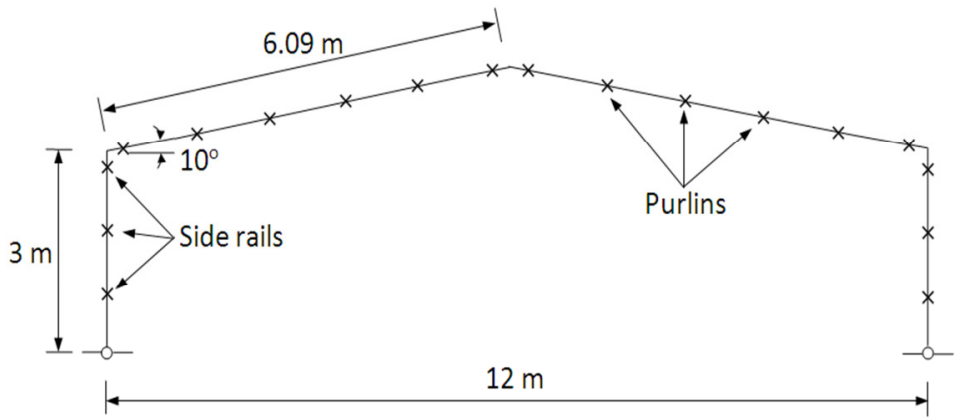

Figure 6: Geometry of internal frame of building (showing positions of purlins and side rails) 


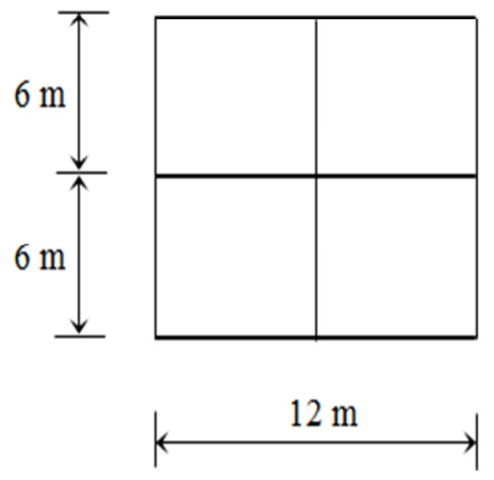

(a) Building A

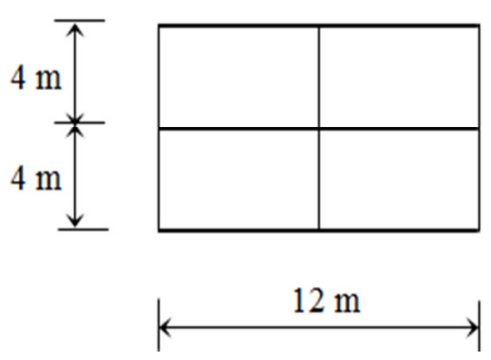

(d) Building D

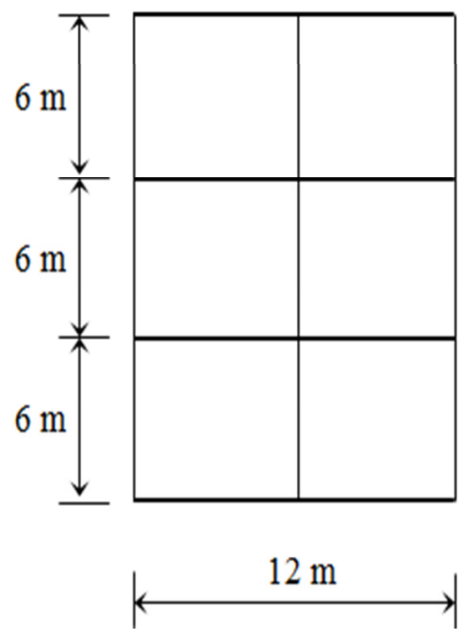

(b) Building B

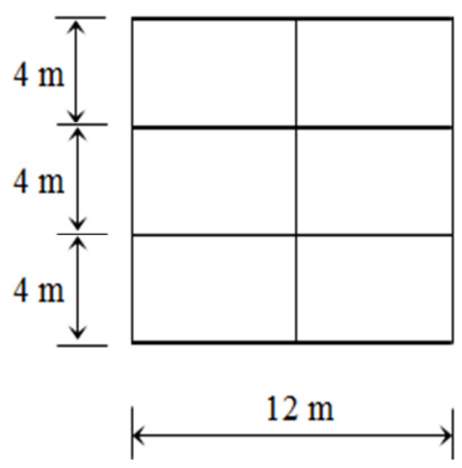

(e) Building E

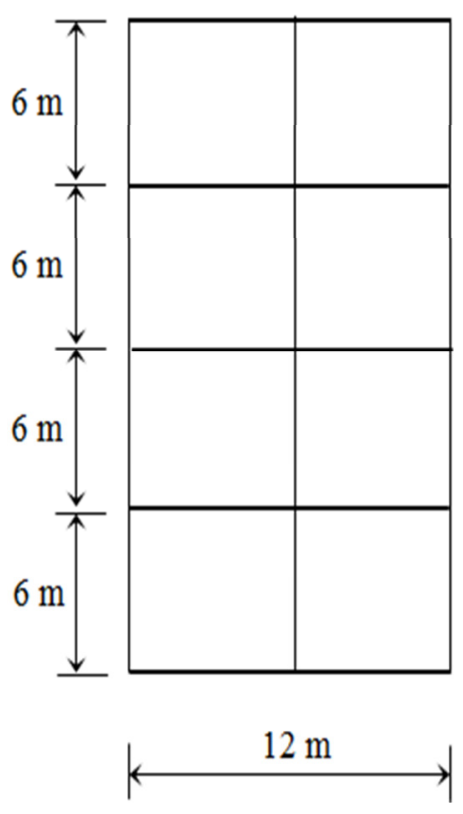

(c) Building $\mathrm{C}$

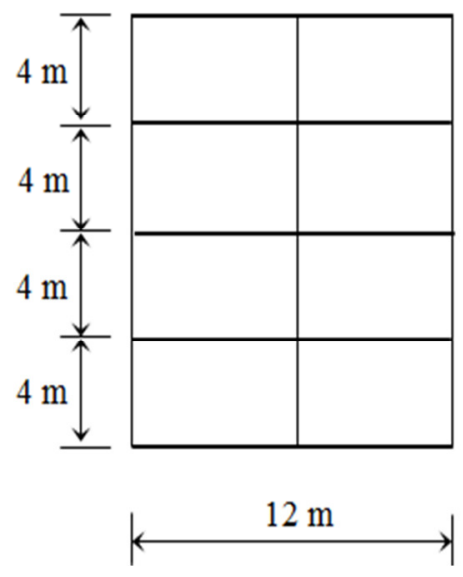

(f) Building F

Figure 7: Plan view of buildings considered to investigate effect of stressed-skin action 


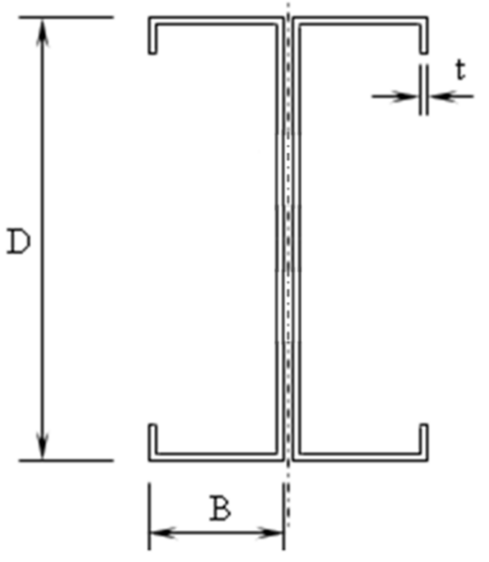

Figure 8: Details of back-to-back cold-formed steel channel-sections
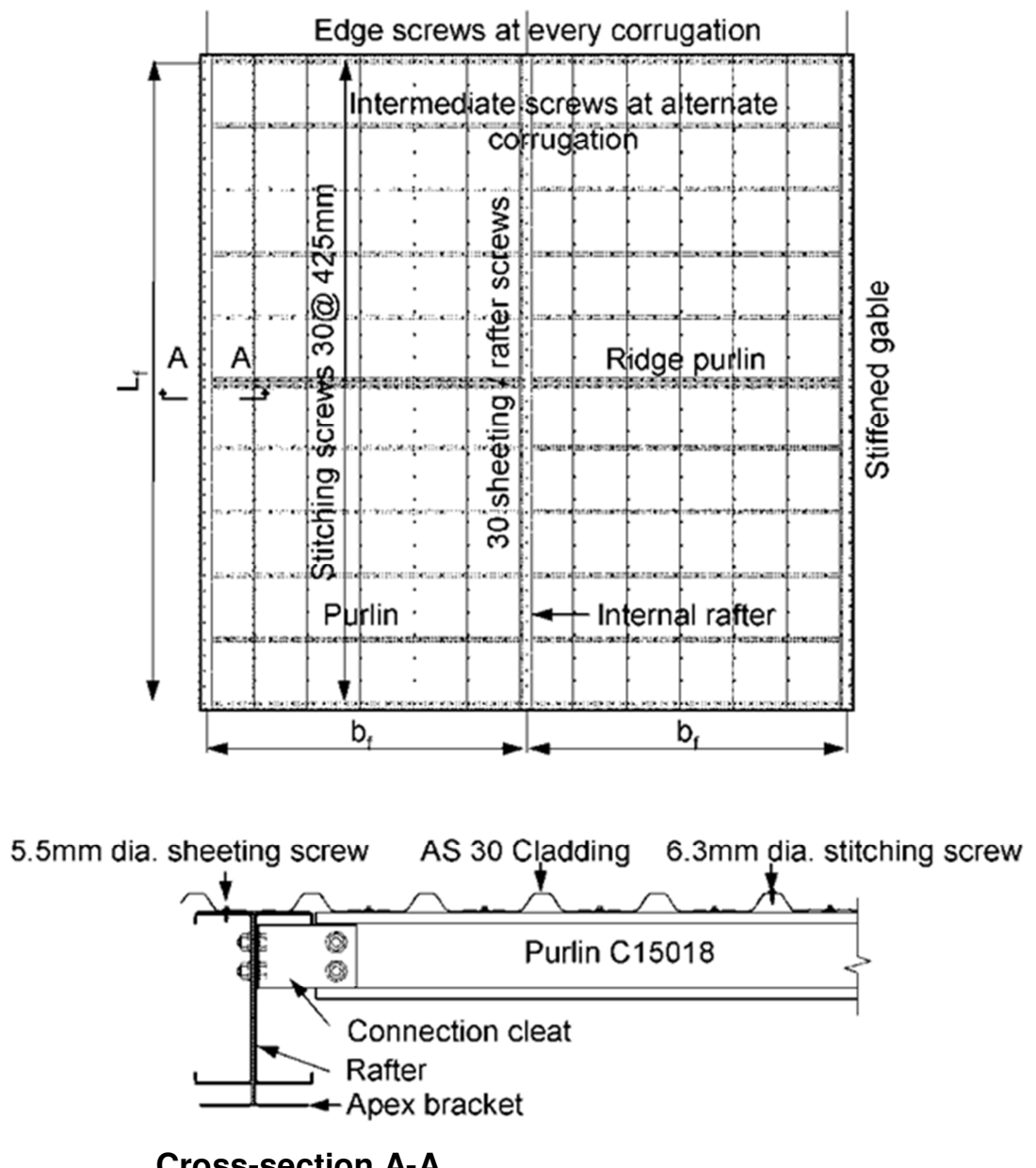

Figure 9: Fastener arrangement of the roof diaphragm 6.09/6/0.7 for internal frame 


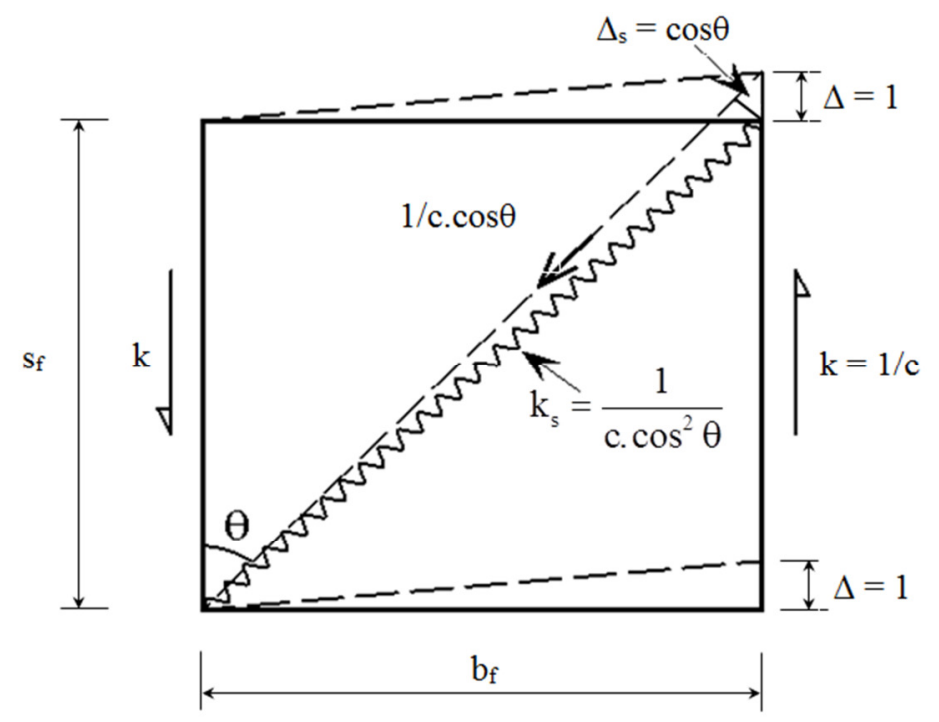

Figure 10: Relationship between diagonal shear stiffness and transverse shear flexibility 


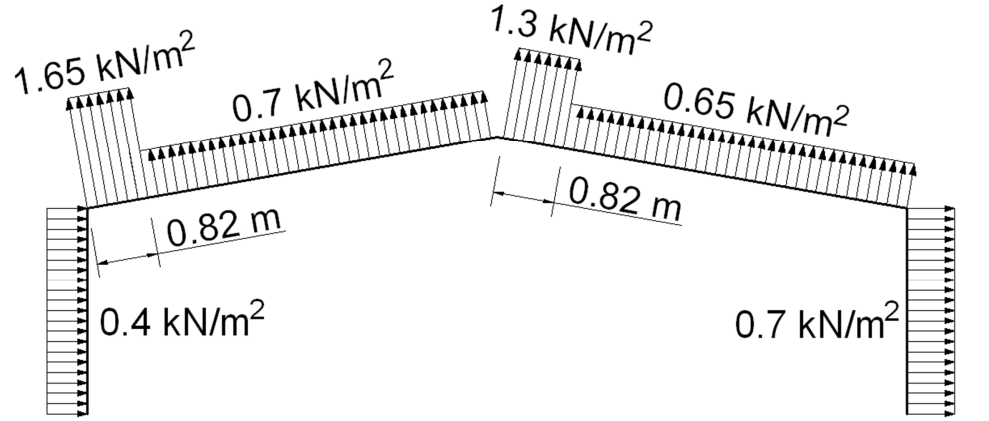

(a) WL1

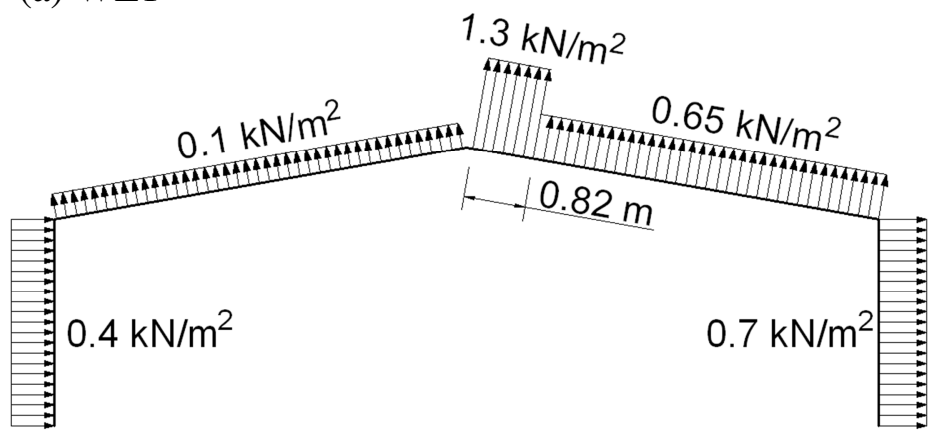

(c) WLC3

$0.8 \mathrm{kN} / \mathrm{m}^{2}$. $0.8 \mathrm{kN} / \mathrm{m}^{2}$

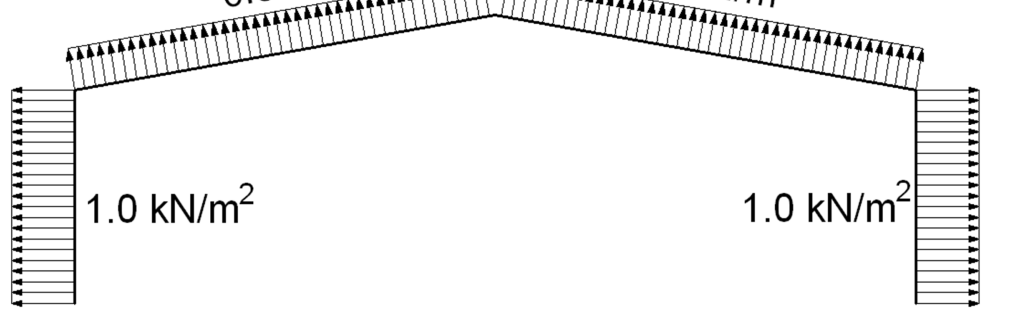

(e) WLC5

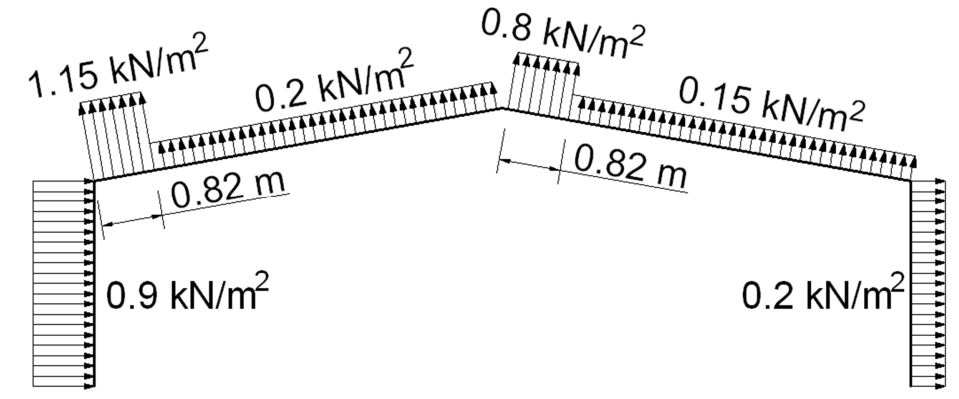

(b) WLC2

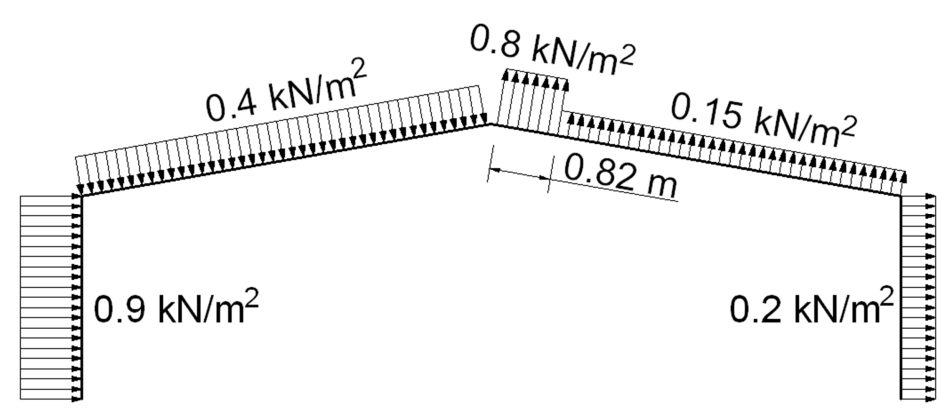

(d) WLC4

$0.3 \mathrm{kN} / \mathrm{m}^{2} \quad 0.3 \mathrm{kN} / \mathrm{m}^{2}$

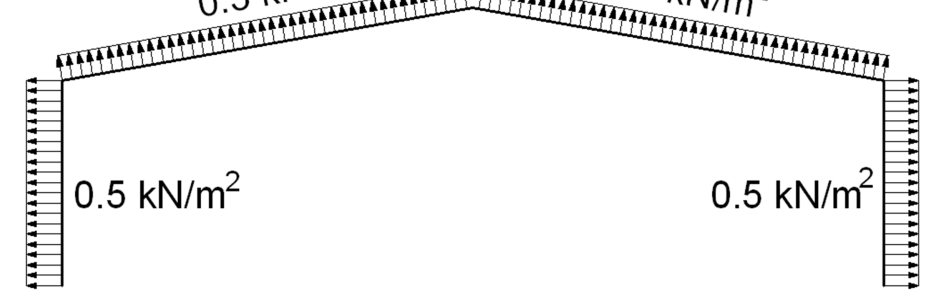

(f) WLC6

Figure 11: Wind load cases (WLCs) 


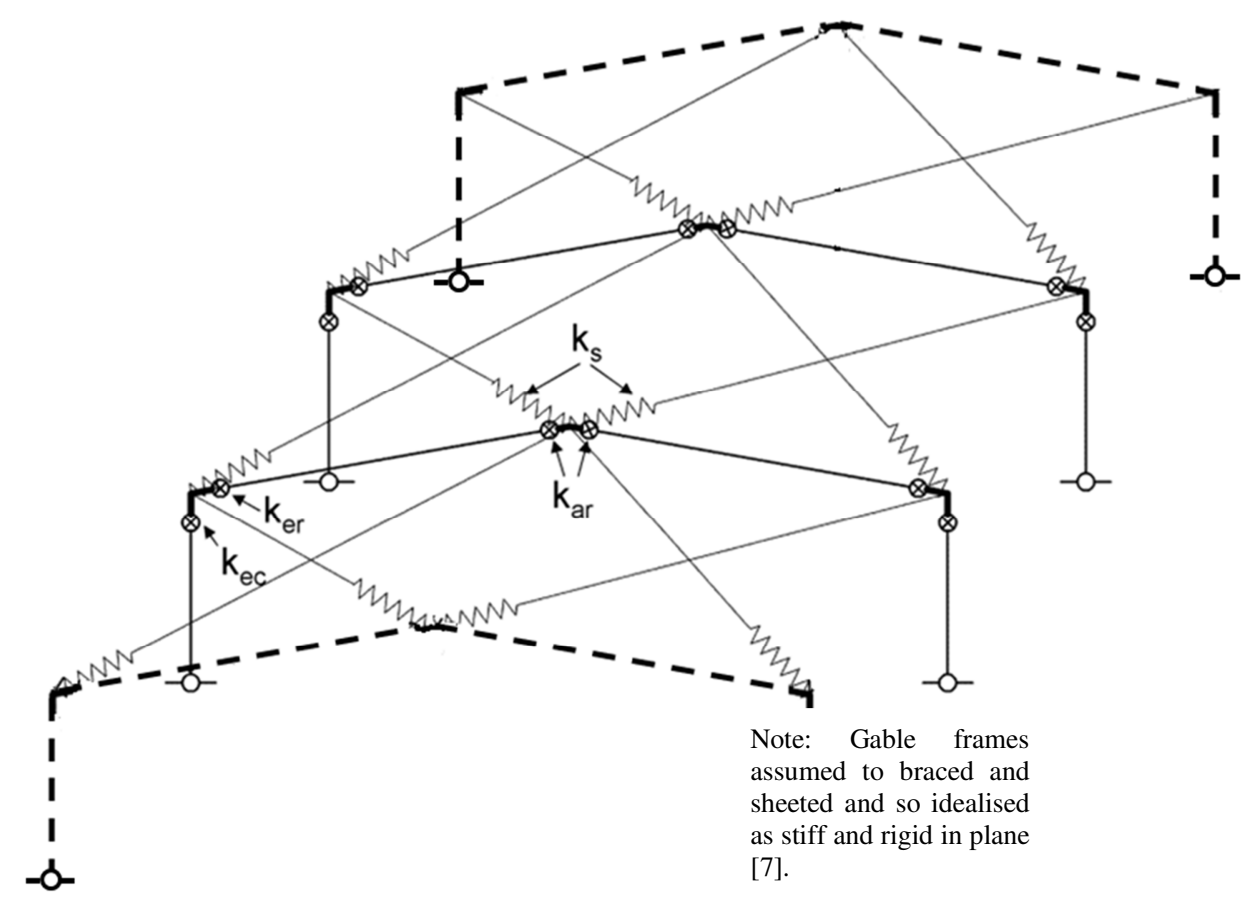

Figure 12: Beam idealization of building having two internal frames (gables idealised as stiff and rigid in-plane; lateral restraints at purlin and side rail positions not shown)

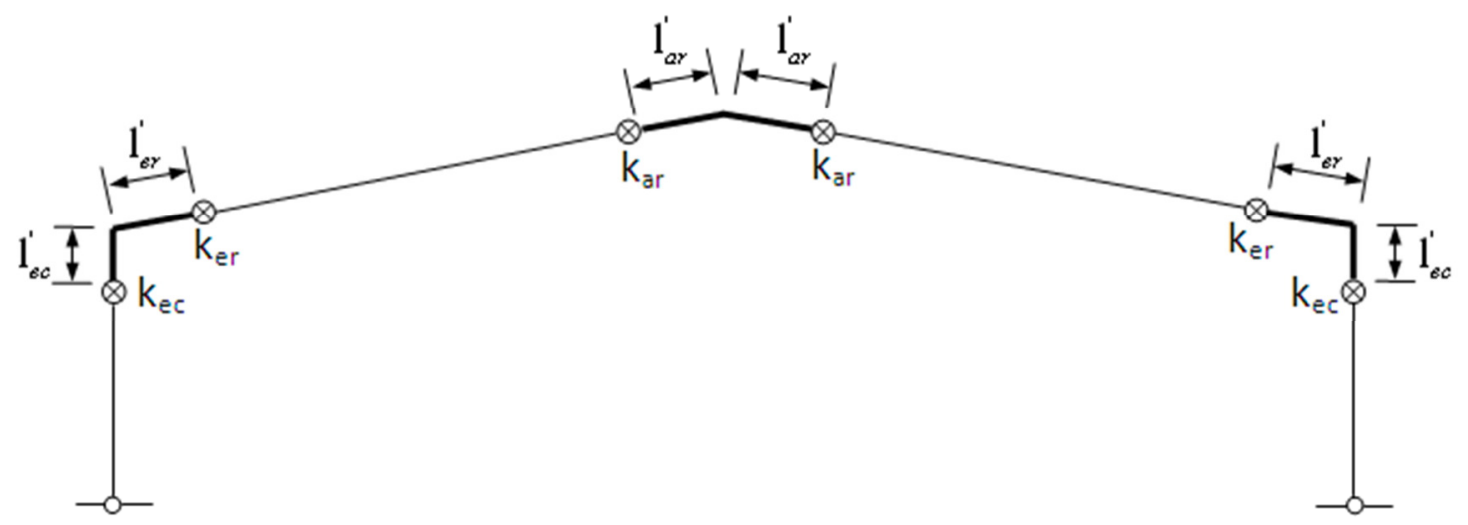

Figure 13: Parameters used to define semi-rigid joints of internal frame 


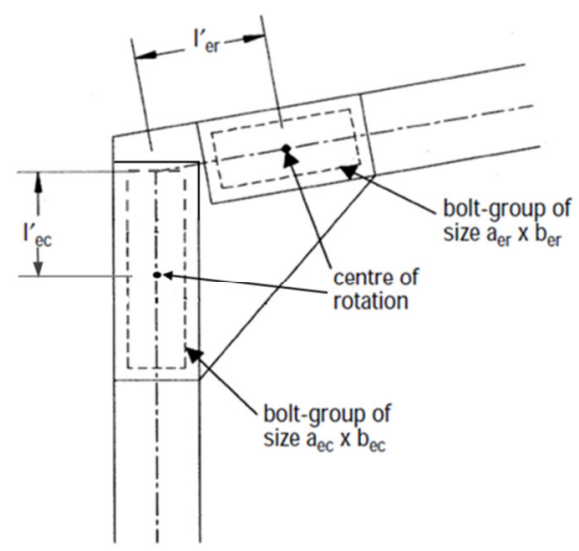

(a) Eaves joint

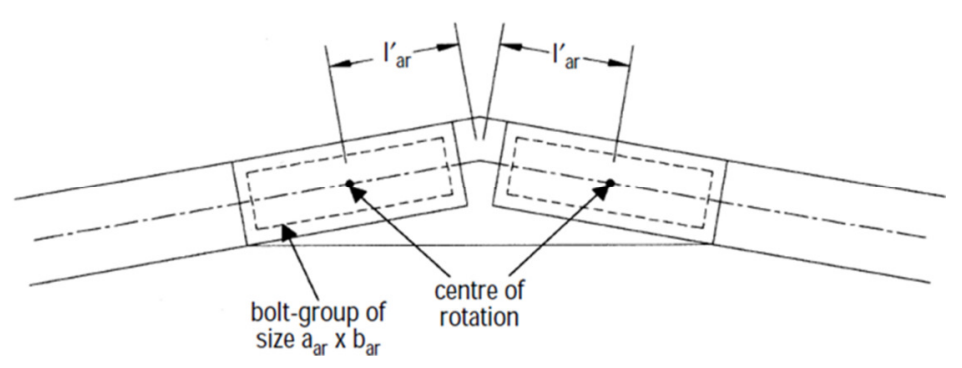

(b) Apex joint

Figure 14: Brackets and bolt-group sizes

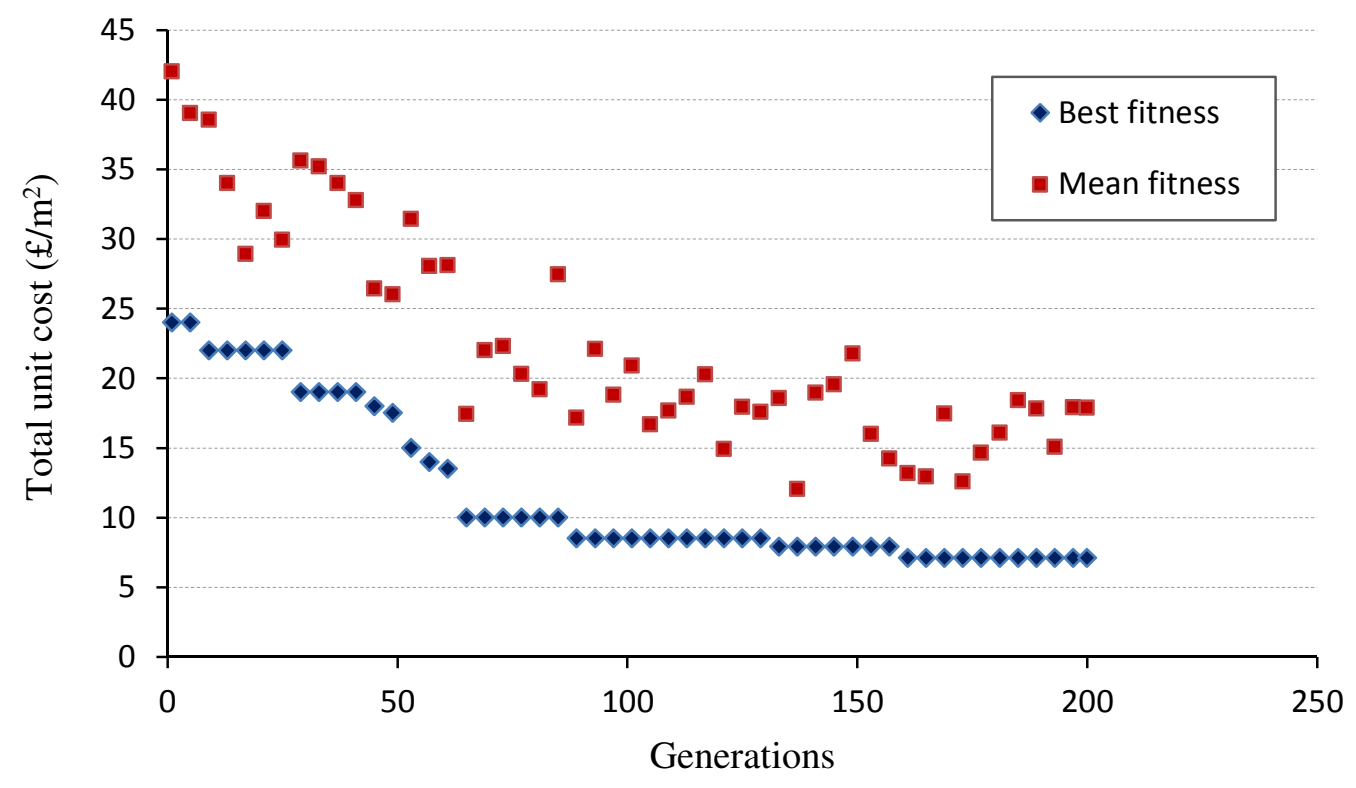

Figure 15: Convergence history for a sample optimization run 


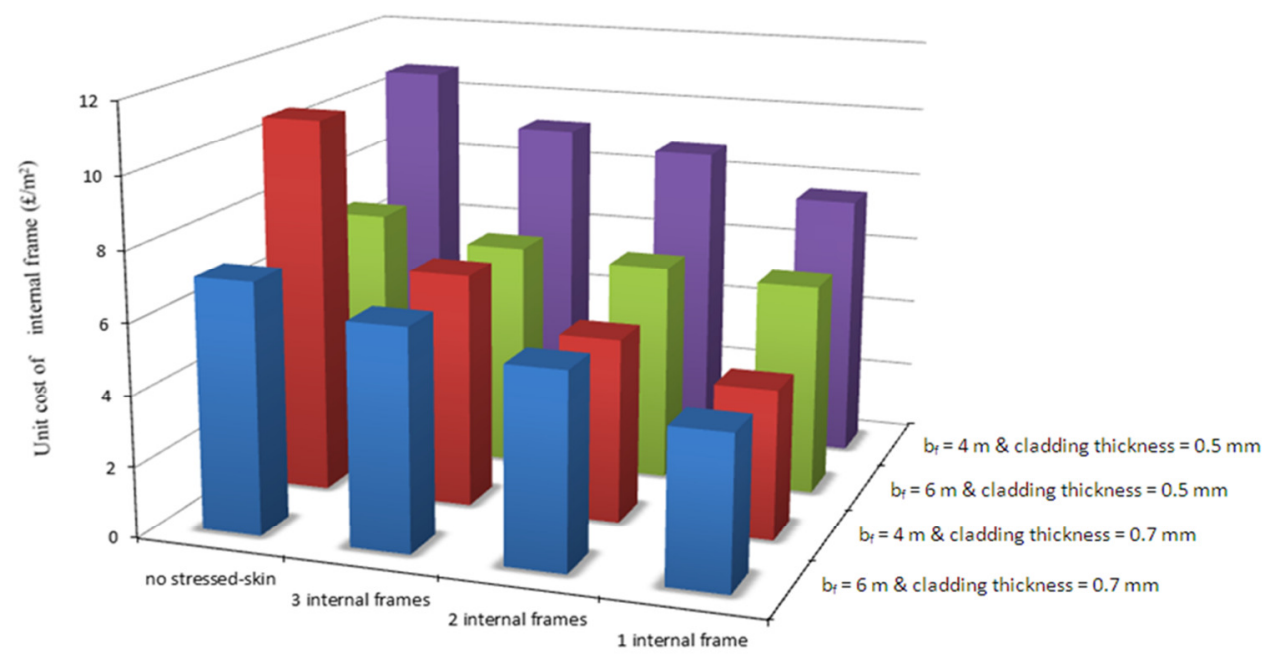

Figure 16: 3D-bar chart of material unit cost of internal frame 